\title{
A morphological and molecular study of Hydrodynastes gigas (Serpentes, Dipsadidae), a widespread species from South America
}

\author{
Priscila S Carvalho ${ }^{\text {Corresp., } 1,2}{ }^{2}$, Hussam Zaher ${ }^{3}$, Nelson J da Silva Jr. ${ }^{4}$, Diego J Santana ${ }^{1}$ \\ 1 Instituto de Biociências, Universidade Federal de Mato Grosso do Sul, Campo Grande, Mato Grosso do Sul, Brazil \\ 2 Instituto de Biociências, Letras e Ciências Exatas, Universidade Estadual Paulista, São José do Rio preto, São Paulo, Brazil \\ 3 Museu de Zoologia da Universidade de São Paulo, São Paulo, São Paulo, Brazil \\ 4 Escola de Ciências Médicas, Farmacêuticas e Biomédicas, Pontifícia Universidade Católica de Goiás, Goiânia, Goiás, Brazil \\ Corresponding Author: Priscila S Carvalho \\ Email address: pricarvalho.bio@gmail.com
}

Background. Studies with integrative approaches (based on different lines of evidence) are fundamental for understanding the diversity of organisms. Different data sources can improve the understanding of the taxonomy and evolution of snakes. We used this integrative approach to verify the taxonomic status of Hydrodynastes gigas (Duméril, Bibron \& Duméril, 1854), given its wide distribution throughout South America, including the validity of the recently described Hydrodynastes melanogigas Franco, Fernandes \& Bentim, 2007. Methods. We performed a phylogenetic analysis of Bayesian Inference with mtDNA 16S and Cytb, and nuDNA Cmos and NT3 concatenated (1902 bp). In addition, we performed traditional morphometric analyses, meristic, hemipenis morphology and coloration pattern of $H$. gigas and $H$. melanogigas. Results. According to molecular and morphological characters, $H$. gigas is widely distributed throughout South America. We found no evidence to support that $H$. gigas and $H$. melanogigas species are distinct lineages, therefore, $H$. melanogigas is a junior synonym of $H$. gigas. Thus, the melanic pattern of $H$. melanogigas is the result of a polymorphism of $H$. gigas. Melanic populations of $H$. gigas can be found in the Tocantins-Araguaia basin. 
1 A morphological and molecular study of Hydrodynastes gigas

2 (Serpentes, Dipsadidae), a widespread species from South

3 America

4

Priscila Santos Carvalho ${ }^{1,2}$, Hussam Zaher ${ }^{3}$, Nelson Jorge da Silva Jr. ${ }^{4}$, Diego José Santana ${ }^{1}$

${ }^{1}$ Instituto de Biociências, Universidade Federal de Mato Grosso do Sul, Campo Grande, MS, 8 Brasil.

9 2Instituto de Biociências, Letras e Ciências Exatas, Universidade Estadual Paulista, São José do 10 Rio Preto, SP, Brasil.

$11{ }^{3}$ Museu de Zoologia da Universidade de São Paulo, São Paulo, SP, Brasil.

$12{ }^{4}$ Escola de Ciências Médicas, Farmacêuticas e Biomédicas, Pontifícia Universidade Católica de

13 Goiás, Goiânia, GO, Brasil.

14

Corresponding Author: Priscila Santos Carvalho

Av. Costa e Silva, S/N, Campo Grande, MS, 79070-900, Brasil.

Email address: pricarvalho.bio@gmail.com

\section{Abstract}

Background. Studies with integrative approaches (based on different lines of evidence) are fundamental for understanding the diversity of organisms. Different data sources can improve the understanding of the taxonomy and evolution of snakes. We used this integrative approach to verify the taxonomic status of Hydrodynastes gigas (Duméril, Bibron \& Duméril, 1854), given its wide distribution throughout South America, including the validity of the recently described Hydrodynastes melanogigas Franco, Fernandes \& Bentim, 2007.

Methods. We performed a phylogenetic analysis of Bayesian Inference with mtDNA 16S and Cytb, and nuDNA Cmos and NT3 concatenated (1902 bp). In addition, we performed traditional morphometric analyses, meristic, hemipenis morphology and coloration pattern of $H$. gigas and H. melanogigas.

Results. According to molecular and morphological characters, $H$. gigas is widely distributed throughout South America. We found no evidence to support that $H$. gigas and H. melanogigas species are distinct lineages, therefore, $H$. melanogigas is a junior synonym of $H$. gigas. Thus, the melanic pattern of $H$. melanogigas is the result of a polymorphism of $H$. gigas. Melanic populations of $H$. gigas can be found in the Tocantins-Araguaia basin.

\section{Introduction}

38 Species are considered lineages with distinct evolutionary histories (de Queiroz, 2007). 
40 Franco et al. 2017; França et al. 2018; Meneses-Pelayo \& Passos 2019). However, in many 41 cases, species are difficult to delimit due to the limited number of morphological differences or 42 the absence of them, preventing the recognition of valid cryptic species (Bickford et al., 2007). 43 Morphology alone might result in more than one name being assigned to individuals belonging 44 to the same evolutionary lineage (i.e. species) (Passos \& Prudente, 2012; Passos, Martins \& 45 Pinto-Coelho, Mângia et al. 2020). Many species are described based solely on morphological 46 patterns, which could merely reflect interpopulational variation, instead of evidence of lineage 47 separation (e.g. Brusquetti et al., 2014; Mângia et al., 2020).

48 Currently, species delimitation must be based on the integration of more than one type of data set 49 (e.g., DNA sequences, morphology, behavior, pheromone), which helps improve taxonomic 50 understanding (Dayrat, 2005; Padial \& De la Riva 2010; Padial et al., 2010; Pante, Schoelinck \& Puillandre, 2014). An integrative approach contributes to taxonomic, phylogenetic and phylogeographic studies (Pante, Schoelinck \& Puillandre, 2014), being thus useful in delimiting species and sorting possible interspecific variations and lineages with similar morphologies. Ultimately, integrative approaches are essential for testing taxonomic schemes and correcting nomenclatural inconsistencies (e.g., Recoder et al. 2014; Ruane et al. 2018; Mângia et al., 2020). Among the morphological characteristics adopted in taxonomic studies that usually result in inaccurate nomenclatural decisions are coloration pattern variations (e.g. Atractus spp.: Passos, Martins \& Pinto-Coelho, 2016; Apostolepis spp.: Entiauspe-Neto et al., 2019). Animal coloration has several adaptive functions, including thermoregulation, signaling and protection (Briolat et al., 2019). Variation in coloration patterns (polychromatism), often associated with ontogenetic dimorphism (e.g., Corallus spp.: Henderson, 1997; Henderson, Passos \& Feitosa 2009; and Drymoluber spp.: Costa, Moura \& Feio, 2013) or with chromatic anomalies such as leukism, albinism and melanism (the latter caused by the increase of epidermal pigments known as melanin; Kettlewell, 1973) can lead to erroneous nomenclatural decisions. Although there are some exclusively melanistic species (e.g., some species of the Pseudoboini tribe), melanism can also be the result of intraspecific polymorphism (e.g., Bernardo et al., 2012). The adaptive value of melanism may be related to predation, protection or thermoregulation (Andrén \& Nilson, 1981; Forsman \&Ås, 1987; Capula, Luiselli \& Monney 1995; Briolat et al., 2019).

Hydrodynastes Fitzinger, 1843 is a genus of large semiaquatic snakes, which currently contains three species: Hydrodynastes bicinctus (Hermann, 1804) distributed in Colombia, Venezuela, French Guiana, Guyana, Suriname and Brazil (Murta-Fonseca, Franco \& Fernandes, 2015); Hydrodynastes gigas (Duméril, Bibron \& Duméril, 1854) distributed in French Guiana, Bolivia, Paraguay, Argentina and Brazil (Giraudo \& Scrocchi, 2002; Pereira-Filho \& Montingelli, 2006; Wallach, Williams \& Boundy, 2014; Nogueira et al., 2019); and Hydrodynastes melanogigas Franco, Fernandes \& Bentim, 2007 recorded only in the Tocantins-Araguaia Basin in the states of Tocantins, Mato Grosso and Maranhão, Brazil (Silva Jr. et al., 2012; Santos Jr. et al., 2017). Hydrodynastes gigas (Duméril, Bibron \& Duméril, 1854) has a wide distribution throughout Brazil, and has been recorded in the states of Amapá, Amazonas, Pará, Rondônia, Roraima, 
79 Tocantins, Maranhão, Piauí, Rio Grande do Norte, Mato Grosso, Mato Grosso do Sul, Minas

80 Gerais, São Paulo, Paraná, Rio Grande do Sul (Nogueira et al., 2019).

81 Given the wide distribution of Hydrodynastes gigas in South America, a level of intraspecific

82 variation throughout its populations is to be expected, with some potential to represent still

83 undescribed cryptic species. Indeed, Franco, Fernandes \& Bentim (2007) considered one of these

84 populations as a distinct species, describing $H$. melanogigas mainly through its differential color

85 pattern and pointed out its similarity with $H$. gigas on meristic and hemipenial characteristics.

86 Therefore, the distinction between $H$. melanogigas and $H$. gigas rests mainly on its melanistic

87 color pattern and on its inferred allopatric distribution with $H$. gigas. The present study aims to

88 evaluate the taxonomic validity of Hydrodynastes gigas and Hydrodynastes melanogigas using

89 an integrative taxonomic approach inferred by molecular and morphological data.

90

91

92

\section{Materials \& Methods}

93

94

95

96

97

98

99

100

101

102

103

104

105

106

107

108

109

110

111

112

113

114

115

116

117

We evaluated the taxonomic status of Hydrodynastes gigas and Hydrodynastes melanogigas by sequencing two mitochondrial and two nuclear genes for 32 individuals belonging to the two species. We further analyzed the external morphology of 186 specimens of $H$. gigas and $H$. melanogigas.

\section{Molecular analysis}

We extracted the DNA from muscle, liver or scale of 27 samples of Hydrodynastes gigas, five of H. melanogigas and 12 of H. bicinctus. Samples of Hydrodynastes bicinctus were added to our analysis in order to provide a complete species representation for the genus. We used the phenolchloroform extraction protocol (Sambrook, Fritsch \& Maniatis, 1989) (Fig.1a). We amplified the partial sequences of the mitochondrial $16 \mathrm{~S}$ ribosomal (mtDNA) genes (16S rRNA, $326 \mathrm{pb}$ )

(Palumbi et al., 2002), Cytochrome b (Cytb, 618 pb) (Pook, Wüster \& Thorpe, 2000), the nuclear genes (nuDNA) Oocyte maturation factor Mos (Cmos, 478 pb) (Lawson et al., 2005) and Neurotrophin-3 (NT3, $480 \mathrm{pb}$ ) (Townsend et al., 2008) using the standard Polymerase Chain Reaction (PCR) technique as described by Pook, Wüster \& Thorpe, 2000 and Moraes-Da-Silva et al. (2019). We visually checked all nucleotide sequences and aligned the concatenated genes (1902 pb) using the Muscle algorithm (Edgar, 2004) in the Geneious v.9.1.8 program

${ }^{\circledR B}$ Biometters. We used the species Pseudoboa nigra and Xenopholis scalaris as outgroup of Hydrodynastes (Vidal, Dewynter \& Gower, 2010; Zaher et al., 2019), and rooted the tree in Xenopholis. We used the sequences available in GenBank and deposited those generated in this study into the same database (Table 1).

We used PartitionFinder 2 to identify partitioning schemes and the most appropriate nucleotide replacement models (Lanfear et al., 2016). According to our concatenated alignment, we found five partitions evaluated by BIC (Table 2). For phylogenetic analysis, we used the Bayesian inference implemented in MrBayes v3.2.6 (Ronquist \& Huelsenbeck, 2003) using the

118 substitution models generated by PartitionFinder. We ran two independent runs of four Markov 
119 chains for 20 million generations sampling every 5,000 generations and discarding $25 \%$ as burn-

120

121

122

123

124

125

126

127

128

129

130

131

132

133

134

135

136

137

138

139

140

141

142

143

144

145

146

147

148

149

150

151

152

153

154

155

156

157

158

in. We evaluated the stability of the analysis in Tracer v1.6, ensuring that all ESS values were above 200 (Rambaut et al., 2014). We calculated the divergence between sequences (distance $p$ ) in Mega v10.0.5 (Tamura et al., 2013).

\section{Morphological analysis}

We examined 144 specimens of Hydrodynastes gigas and 42 specimens of H. melanogigas (Fig. 1b). Museum acronyms follow Sabaj Pérez (2014), except for Coleção Herpetológica da Universidade Federal da Paraíba (CHUFPB), João Pessoa, PB; Coleção Zoológica Delta do Parnaíba (CZDP), Parnaíba, PI; Universidade Luterana do Brasil (MZCEULP), Palmas, TO. The specimens examined are listed in the Appendix 1.

Franco, Fernandes \& Bentim (2007) described Hydrodynastes melanogigas based on 17 specimens collected in the municipalities of Palmas (type locality), Porto Nacional, and Lajeado, which are all located in the state of Tocantins, Brazil. Unfortunately, most of the type series was lost in the 2010 fire that occurred at the Instituto Butantan. Currently, only three individuals remain from the type series: two at the proper Institute in São Paulo (paratypes IBSP 65978 and IBSP 66387) and one at the Museu Nacional do Rio de Janeiro (paratype MNRJ 15101). From the remaining type-series, we analyzed all the remaining individuals.

We examined 14 meristic characters (Table 3) and eight morphometric ones (Table 4), in addition to the coloration pattern and morphology of the hemipenis. Sex was determined by the presence or absence of hemipenes through a ventral incision at the base of the tail. We measured individuals with an electronic caliper $(0.01 \mathrm{~mm})$ and a flexible ruler $(1 \mathrm{~mm})$, on their right side whenever possible. In order to test morphometric differences between $H$. gigas and $H$. melanogigas, we conducted a principal component analysis (PCA) and took the first two principal components of the ordination to create a MANOVA. We ran this analysis with adult males and females separately, and performed the analysis in R software (R Core Team 2014) using the package Vegan (Oksanen 2007). We followed the terminology of Dowling (1951) for counting the ventral scales, and Peters (1964) and Vanzolini, Ramos-Costa \& Vitt (1980) for pholidosis. We surveyed the geographic coordinates of the data catalogs of zoological collections using Google Earth software.

\section{Hemipenial morphology}

We prepared a hemipenis from a topotype of Hydrodynastes melanogigas and 19 from $\mathrm{H}$. gigas from different localities in the Amazon, East Brazil and La Plata hydrobasins (Appendix 1). Whenever possible, we prepared the hemipenes on the right side according to the technique originally described by Manzani \& Abe (1988), as modified by Pesantes (1994), Zaher (1999), and Zaher \& Prudente (2003). We stained the external calcareous structures with alizarin red, as suggested by Nunes et al. (2012), for a better visualization of microstructures in the surface of the organ. Terminology follows Dowling \& Savage (1960), Zaher (1999) and Myers \& Cadle (2003).

PeerJ reviewing PDF | (2020:04:48410:2:0:NEW 5 Sep 2020) 
159 Results

\section{Molecular approach}

161 We recovered the genus Hydrodynastes as monophyletic, and the topology of the concatenated

162 gene tree showed two strongly supported clades with posterior probability ( $\mathrm{pp}=1.00)$. Our

163 concatenated dataset tree grouped Hydrodynastes melanogigas within H. gigas (Fig. 2). The

164 uncorrected p-distance for both the mtDNA 16S and Cytb showed low genetic differences

$165(0.01 \%$ and $0.2 \%$, respectively) between the lineages of $H$. gigas and $H$. melanogigas. However, 166 the genetic differences between $H$. gigas and $H$. bicinctus were $0.43 \%$ for $16 \mathrm{~S}$ and $13 \%$ for Cytb

167 (Table 5). Intraspecific variation in $H$. gigas was $0.0 \%$ to $0.04 \%$ for $16 \mathrm{~S}$ and $0.0 \%$ to $0.17 \%$ for

168 Cytb, while in H. bicinctus it was $0.0 \%$ for $16 \mathrm{~S}$ and $0.0 \%$ to $0.23 \%$ for Cytb (Supplementary

169 Material).

170 Morphological approach

171 We found overlap in all meristic and morphometric characteristics between Hydrodynastes gigas 172 and $H$. melanogigas (Table 3 and 4). The first principal components from both PCA analysis

173 (males and females) recovered $99 \%$ of variation, and through the MANOVA of males $(\mathrm{F}=$

$1742.2949 ; \mathrm{p}=0.1109)$ and females $(\mathrm{F}=0.3463 ; \mathrm{p}=0.7095)$ we found no significant morphometric

175 differences between both species (Fig. 3). In addition, we observed gradient levels of melanism

176 in H. melanogigas (Figs. 4a-f). We examined fully melanic specimens (Fig. 4a) to specimens

177 with clear visible bands along the body (Fig. 4f). We also observed that some H. gigas

178 individuals from the Amazon, La Plata and Tocantins-Araguaia basins present darker coloration

179 overlapping the gradient of melanism found in H. melanogigas (Figs. 5a-f). We did not find any

180 morphological characteristics that differentiate the two species.

181 We did not observe coloration patterns within or between the populations of Hydrodynastes

182 gigas (Figs. 6a-f). We observed ontogenetic variation in the color pattern of all populations

183 analyzed, with no distinction between males and females. Juveniles in the early stages of life

184 have well-defined rounded dark spots all over their backs to the end of their tails; these spots are

185 outlined by a lighter line, while in adults rounded spots may or may not be well defined, and may

186 not present a clear outline (Figs. 7a-e). Furthermore, we identified two young males of $\mathrm{H}$. gigas

187 (CHUNB 22053, Figs.7e; CHUNB 22068) from the type locality of $H$. melanogigas, as well as

18818 more specimens from the Tocantins-Araguaia Basin. We provide more details in the

189 "variation" section below.

190 Hemipenis morphology (Figs. 8a-j): When fully everted and expanded, hemipenes of $H$.

191 melanogigas and H. gigas are undistinguishable (Figs. 8k-1). The hemipenis is deeply bilobed,

192 semicaliculate and semicapitate, with three or four vertical rows of large spines arranged on each

193 side of the body. The body of the hemipenis is covered by spikes on the sulcate and assulcate

194 faces. The sulcus spermaticus bifurcates in the proximal region of the hemipenis body and each

195 branch extends centrolinearly until it reaches the proximal region of the lobes, in which they

196 follow a centrifugal position that ends at the lateral region of the tip of each. The capitulum,

197 formed by papillate calyces and spikes, extends over most of the surface of the lobes, except in

198 the region of the assulcate face that is occupied by two parallel rows of papillated and 
199

200

201

202

203

204

205

206

207

208

209

210

211

212

213

214

215

216

217

218

219

220

221

222

223

224

225

226

227

228

229

230

231

232

233

234

235

236

237

238

conspicuous body calyces that extend to the distal region of the hemipenis body, where they converge on the lobular crest and continues to the middle portion of the hemipenis. We detected low intraspecific variation among Hydrodynastes gigas populations. Some hemipenes showed little size variation in lobes and body calyces, varying from slightly visible to conspicuous in the hemipenial body.

\section{Discussion}

Hydrodynastes gigas is widely distributed throughout South America, occurring with low genetic variability throughout most of its extension range. Although the genetic structure of widely distributed species can be easily influenced by natural barriers (Patton, da Silva \& Malcolm, 1994; Pellegrino et al., 2005; Rocha et al., 2015), this clearly is not the case for the genus Hydrodynastes (see Murta-Fonseca, Franco \& Fernandes, 2015).

Here, we used an integrative taxonomic approach and adopted the species concept of one lineage with distinct evolutionary histories (de Queiroz, 2007), to test the taxonomic validity of Hydrodynastes melanogigas. Our results did not separate $H$. gigas and $H$. melanogigas based on molecular, meristic, morphometric and hemipenial characters. The hemipenis of Hydrodynastes melanogigas analyzed showed no differences from the hemipenis of $H$. gigas $(\mathrm{n}=19)$. In their description of $H$. melanogigas, Franco, Fernandes \& Bentim (2007) also pointed out its similarity with $H$. gigas based on meristic characters and hemipenis morphology. The only superficial distinction that remains between these two taxa is the presence of melanism in the latter. Geographic or regional melanism has already been reported for several populations of Squamata (Pearse \& Pogson, 2000; King, 2003; Bernardo et al., 2012). In addition,

polychromatism can be a bias within taxonomy, if the revision and/or description of species does not take into account the organisms throughout their whole distribution (Bernardo et al. 2012; Ruane et al. 2018; Mângia et al. 2020). In fact, Franco, Fernandes \& Bentim (2007) carried out an analysis covering almost the entire distribution of $\mathrm{H}$. gigas, however we found degrees of melanism in some populations that were not identified by other authors. The variation of melanism found in H. gigas and the melanistic gradient observed in H. melanogigas (Figs. 4 and 5), along with genetic support, suggests that $H$. melanogigas is not a distinct species but rather a melanic population of $\mathrm{H}$. gigas. The distribution of Hydrodynastes melanogigas without sympatry with $H$. gigas in the Tocantins-Araguaia basin was an important factor for its description (Franco, Fernandes \& Bentim, 2007). However, in this study, we analyzed two juveniles of $\mathrm{H}$. gigas from the type locality of $\mathrm{H}$. melanogigas (CHUNB 22053, Fig.7e; CHUNB 22068). All specimens analyzed by Franco, Fernandes \& Bentim (2007) and herein were adults or juveniles and no neonates were observed. Therefore, we do not know whether the specimens considered as $H$. melanogigas could have been born melanic or if melanism occurs during their ontogeny. Still, some studies suggest that thermal melanism is associated with latitude and high altitudes, i.e., relatively cold environments (Capula, Luiselli \& Monney, 1995), which does not agree with the present case. More studies are needed to confirm the adaptive meaning of

Peer) reviewing PDF | (2020:04:48410:2:0:NEW 5 Sep 2020) 
239 melanism through studies of thermal biology. Therefore, due to the lack of any characteristic that 240 sustain these two taxa as distinct species and their low genetic distance $(0.04 \% 16 \mathrm{~S}$ and $0.2 \%$ 241 Cytb), we consider H. melanogigas Franco, Fernandez \& Bentim, 2007 as a junior synonym of 242 H. gigas (Duméril, Bibron \& Duméril, 1854).

243

244 Systematic account

245 Hydrodynastes gigas (Duméril, Bibron \& Duméril, 1854)

246 Xenodon gigas Duméril, Bibron \& Duméril, 1854. Erpétologie générale vol. 7: 761.

247 Lejosophis gigas Jan, 1863. Elenco Sistematico degli Ofidi descriti e disegnati per l'Iconografia 248 Generale. vol. 2: 56.

249 Cyclagras gigas Cope, 1885. Proceeding of the American Philosophical Society: 185.

250 Cyclagras gigas Boulenger, 1894. Catalogue of the snakes in the British Museum vol. 2: 144.

251 Lejosophis gigas Dunn, 1944. Caldasia: 69.

252 Lejosophis gigas Hoge, 1958. Papéis Avulsos de Zoologia: 222.

253 Hydrodynastes gigas Hoge, 1966. Ciência e Cultura: 143.

254 Cyclagras gigas Peters \& Orejas-Miranda 1970. Catalogue of the Neotropical Squamata. Part I: 25578.

256 Hydrodynastes gigas Dowling \& Gibson, 1970. Herpetological Review (2): 38

257 Hydrodynastes melanogigas Franco, Fernandes \& Bentim, 2007 Zootaxa (1613): 58. New

258 Synonymy

259

260 Type material: syntype MNHN 3623

261 Type locality: Corrientes Province, Argentina.

262

263

264

265

266

267

268

269

Comments on the type series: Duméril, Bibron and Duméril's (1854) description of Xenodon gigas did not refer to any voucher specimen. The authors only cited that M. A. d'Orbigny collected three individuals in Rio de La Plata, Corrientes Province, Argentina (without further information). The authors also mentioned a plate (Xénodon géant. Atlas, pi. 76, fig-5), which only presents a cranial picture. Overall, Wallach, Williams \& Boundy (2014, p. 339) indicate that the types would be MNHN 2493 a-c, but according to Uetz et al., (2019), it would be an individual labeled MNHN 3623. Due to this conflicting information, we contacted the curator of

270

271 the Herpetological Collection at the Muséum National d'Histoire Naturelle de Paris (Dr. N.

272 deposited in the collection, and that the other two specimens appear to be lost . Since Duméril, Vidal) who confirmed that there is only one type specimen, a skin labeled MNHN 3623 (Fig. 9),

273 Bibron \& Duméril (1854) did not select any specific specimen from their type series, we 274 therefore, designate the specimen MNHN 3623 as the lectotype of Hydrodynastes gigas.

275 Description of the lectotype MNHN 3623 (Fig. 9): Adult of undetermined sex; SVL 1570mm; 276 TL 540mm; HL 62mm; HW 35mm; DN 10mm; two internasals; nasal divided; one loreal; one 277 preocular; three suboculars; two postoculars; temporal $2+2 / 2+2$; nine supralabials, none 278 contacting the orbit; eleven infralabials, first to sixth contacting chin shields on the right side and 
279 first to fifth on the left side; two pairs of chin shields; dorsal 19/16/15 scales, smooth; two apical 280 pits; ventral 153; subcaudals 74, paired and cloacal scale single.

281 Color of the preserved lectotype (ethanol 70\%) (Fig. 9): Head brown with black 'U' shaped 282 spot at the end of the parietal scale; post-ocular stripe that extends longitudinally on each side; 283 supralabial brown with the last four scales stained black; infralabials and chin shields cream; 284 dorsum of body brown with dark rounded spots that extend to the end of the tail; ventral body 285 cream with three black stripes to the middle of the body.

286 Diagnosis: Hydrodynastes gigas is distinguished from its congener H. bicinctus by the following 287 combination of characters: dorsal scales normally 19/19/15; ventral scales in males 150-168 and 288 in females 152-172; subcaudal scales in males 58-88 and in females 49-84; maxillary teeth 15289 17; two apical pits in the dorsal scales; post-ocular stripe that extends longitudinally (on each 290 side); ventral body with three lines of continuous spots up to the middle of the body.

291 Variation: All variation in morphometric and meristic data are presented in Tables 3 and 4.

292 Regarding coloration patterns, a considerable degree of color variation can be found in $H$. gigas

293 (Figs. 4a-f; Figs. 5a-f; Figs. 6a-f and Figs. 7a-e) dorsum ranging from yellow to dark brown or 294 completely dark in melanic populations; rounded spots on the dorsum may vary in shape and 295 size, in some individuals they may be hollow or filled; in neonates the dark rounded spots are 296 well defined throughout the dorsum until the end of the tail, and these spots are outlined by a 297 lighter line; darks spot in the shape of ' $V$ ' or ' $U$ ' at the end of the parietal scale, only visible in 298 non-melanic populations; ventral body cream/brown with three black stripes that usually go up to 299 the middle of the body, rarely to the cloaca, some individuals do not have these stripes, in 300

301 melanic populations the belly is dark without spots or when present these spots are continuous on the sides.

302 Distribution: Hydrodynastes gigas is widely distributed throughout South America, east of the

303 Andes, occurring in Amazon, East Brazil, La Plata, North Brazil, Northeast South America,

304 Parnaiba and Tocantins-Araguaia hydrobasins (Fig. 10).

305

306

\section{Conclusions}

308

309

310

311

312

313 314

315

Our results did not separate $H$. gigas and $H$. melanogigas based on molecular, meristic, morphometric and hemipenial characters. Therefore, the melanistic pattern of Hydrodynastes melanogigas is characterized here as the result of polymorphism within H. gigas. Although our integrative approach helped elucidate the taxonomic status of $H$. melanogigas, we believe future, multi-loci phylogeographic studies are needed in order to better understand the evolutionary history of the populations belonging to the two remaining species $H$. gigas and $H$. bicinctus.

\section{Acknowledgements}

We are grateful to G. Puorto and F. Grazziotin (IBSP), G. Colli (CHUNB), D. Mesquita and G. Vieira (CHUFPB), J. Lima (IEPA), P. Manzani (ZUEC), G. Graccioli (ZUFMS), S. Cechin 
319 (ZUFSM), C. Previero (MZCEULP), A. Guzzi (CZDP), F. Resende (FUNED), R. Oliveira 320 (MCN), G. Pontes (MCP), JC. Leite (MNHCI), A. Prudente (MPEG), F. Curcio (UFMT), P.

321 Passos (MNRJ), and N. Vidal (MNHN) for allowing access or loaning specimens under their

322 care. We are indebted to Ana Bottallo Quadros for verifying and photographing the type

323 specimen at the MNHN. We also thank Diego Cavalheri and Roberta Murta-Fonseca for 324 verifying and taking photos from $H$. melanogigas type series specimens at the IBSP and MNRJ.

325

326

327

\section{References}

328

329

330

331

332

333

334

Andrén, C., \& Nilson, G. 1981. Reproductive success and risk of predation in normal and melanistic colour morphs of the adder, Vipera berus. Biological Journal of the Linnean Society. 15(3): 235-246.

Bernardo, P.H., Machado, F.A., Murphy, R.W., \& Zaher, H. 2012. Redescription and morphological variation of Oxyrhopus clathratus Duméril, Bibron and Duméril, 1854

335 (Serpentes: Dipsadidae: Xenodontinae). South American Journal of Herpetology. 7(2): 134-149. doi:10.2994/057.007.0203.

336 Bickford, D., Lohman, D.J., Sodhi, N.S., Ng, P.K., Meier, R., Winker, K., Ingram, K.K., \& Das, 337

338 I. 2007. Cryptic species as a window on diversity and conservation. Trends in Ecology \& Evolution. 22(3): 148-155. doi:10.1016/j.tree.2006.11.004.

339 Boulenger, G.A. 1894. Catalogue of the Snakes in the British Museum (Natural History), Vol. II.

340 Trustees of the British Museum, London.

341 Briolat, E.S., Burdfield-Steel, E.R., Paul, S.C., Rönkä, K.H., Seymoure, B.M., Stankowich, T., \& 342 Stuckert, A.M. 2019. Diversity in warning coloration: selective paradox or the norm?. Biological 343 Reviews. 94(2): 388-414. doi:10.1111/brv.12460.

344 Brusquetti, F., Jansen, M., Barrio-Amorós, C., Segalla, M., \& Haddad, C.F. 2014. Taxonomic 345 review of Scinax fuscomarginatus (Lutz, 1925) and related species (Anura; Hylidae). Zoological 346 Journal of the Linnean Society. 171(4): 783-821. doi:10.1111/zoj.12148.

347 Capula, M., Luiselli, L., \& Monney, J.C. 1995. Correlates of melanism in a population of adders 348 (Vipera berus) from the Swiss Alps and comparisons with other alpine populations. Amphibia349 Reptilia. 16(4): 323-330. doi.org/10.1163/156853895X00406.

350 Cope, E.D. 1885. Twelfth contribution to the herpetology of tropical America. Proceedings of 351 the American Philosophical Society. 22(118): 167-194.

352 Costa, H.C., Moura, M.R., \& Feio, R.N. 2013. Taxonomic revision of Drymoluber Amaral, 1930

353 (Serpentes: Colubridae). Zootaxa. 3716(3): 349-394. doi.org/10.11646/zootaxa.3716.3.3.

354 Dayrat, B. 2005 Towards integrative taxonomy. Biological Journal of the Linnean society. 85(3):

355 407-415. doi.org/10.1111/j.1095-8312.2005.00503.x.

356 De Queiroz, K. 2007. Species concepts and species delimitation. Systematic Biology. 56(6):

357 879-886. doi.org/10.1080/10635150701701083. 
358 Dowling, H.G., \& Savage, J.M. 1960. A guide to the snake hemipenis: a survey of basic structure

359

360

361

362

363

364

365

366

367

368

369

370

371

372

373

374

375

376

377

378

379

380

381

382

383

384

385

386

387

388

389

390

391

392

393

394

395

396

397

and systematic characteristics. Zoologica. 45(1): 17-28.

Dowling, H.G. 1951. A proposed standard system of counting ventrals in snakes. British Journal of Herpetology. 1: 97-99.

Dowling, H.G. 1967. Hemipenes and other characters in colubrid classification. Herpetologica. 23(2): 138-142.

Dowling, H.G., \& Gibson, F.W. 1970. Relationship of the Neotropical snakes Hydrodynastes bicinctus and Cyclagras gigas. Herpetological Review. 2(2): 37-38.

Duméril, A.M.C., Bibron, G., \& Duméril, A. 1854. Erpétologie Genérale ou Histoire Naturelle Complete des Reptiles. Vol. VII. Librairie Encyclopédique de Roret, Paris.

Dunn, E.R. 1944. Dugandia, a new snake genus for the Coluber bicinctus Hermann. Caldasia. 3(11): 69-70.

Edgar, R.C. 2004. MUSCLE: multiple sequence alignment with high accuracy and high throughput. Nucleic Acids Res. 32(5): 1792-1797. doi.org/10.1093/nar/gkh340.

Entiauspe-Neto, O.M., de Sena, A., Tiutenko, A., \& Loebmann, D. 2019. Taxonomic status of Apostolepis barrioi Lema, 1978, with comments on the taxonomic instability of Apostolepis Cope, 1862 (Serpentes, Dipsadidae). ZooKeys. 841: 71-78. doi: 10.3897/zookeys.841.33404. Forsman, A., \& Ås, S. 1987. Maintenance of colour polymorphism in adder, Vipera berus, populations: a test of a popular hypothesis. Oikos. 50(1): 13-16.

França, D.P., Barbo, F.E., Silva-Junior, N.J., Silva, H.L., \& Zaher, H. 2018. A new species of Apostolepis (Serpentes, Dipsadidae, Elapomorphini) from the Cerrado of Central Brazil.

Zootaxa. 4521(4): 438-552. doi 10.11646/zootaxa.4521.4.3.

Franco, F.L., Fernandes, D.S., \& Bentim, B.M. 2007. A new species of Hydrodynastes Fitzinger, 1843 from central Brazil (Serpentes: Colubridae: Xenodontinae). Zootaxa. 1613(1): 57-65.

Franco, F.L., Trevine, V.C., Montingelli, G.G., \& Zaher, H. 2017. A new species of

Thamnodynastes from the open areas of central and northeastern Brazil (Serpentes: Dipsadidae:

Tachymenini). Salamandra. 53(3): 339-350.

Giraudo, A.R., \& Scrocchi, G.J. 2002. Argentinian Snakes: An annotated checklist. Smithsonian Herpetological Information Service. 132: 1-53.

Henderson, R.W. 1997. A taxonomic review of the Corallus hortulanus complex of Neotropical tree boas. Caribbean Journal of Science. 33: 198-221.

Henderson, R.W., Passos, P., \& Feitosa, D. 2009. Geographic variation in the emerald treeboa, Corallus caninus (Squamata: Boidae). Copeia. 3: 572-582.

Hoge, A.R. 1966. Notes on Hydrodynastes [Serpentes - Colubridae]. Ciência e Cultura. 18(2): 143.

Hoge, A.R. 1958. Três notas sobre serpentes brasileiras. Papéis Avulsos do Departamento de Zoologia. Secretaria da Agricultura-São Paulo-Brasil. 3: 221-225.

Jan, G. 1863. Elenco sistematico degli Ofidi descritti e disegnati per l'Iconographia Generale. A. Lombardi, Milan.

Kettlewell, H.B.D. 1973. The evolution of melanism. Clarendon Press, Oxford.

Peer) reviewing PDF | (2020:04:48410:2:0:NEW 5 Sep 2020) 
398

399

400

401

402

403

404

405

406

407

408

409

410

411

412

413

414

415

416

417

418

419

420

421

422

423

424

425

426

427

428

429

430

431

432

433

434

435

436

437

King, R.B. 2003. Mendelian inheritance of melanism in the garter snake Thamnophis sirtalis. Herpetologica 59(4): 484-489. doi.org/10.1655/02-93.

Lanfear, R., Frandsen, P.B., Wright, A.M., Senfeld, T., \& Calcott, B. 2016. PartitionFinder 2: new methods for selecting partitioned models of evolution for molecular and morphological phylogenetic analyses. Molecular Biology and Evolution. 34(3): 772-773. doi.org/10.1093/molbev/msw260.

Lawson, R., Slowinski, J.B., Crother, B.I., \& Burbrink, F.T. 2005. Phylogeny of the Colubroidea (Serpentes): New evidence from mitochondrial and nuclear genes. Molecular Phylogenetics and Evolution. 37(2):581-601. doi:10.1016/j.ympev.2005.07.016.

Mângia, S., Oliveira, E.F., Santana, D.J., Koroiva, R., Paiva, F., \& Garda, A.A. 2020. Revising the taxonomy of Proceratophrys Miranda- Ribeiro, 1920 (Anura: Odontophrynidae) from the Brazilian semiarid Caatinga: Morphology, calls and molecules support a single widespread species. Journal of Zoological Systematics and Evolutionary Research. doi:10.1111/jzs.12365. Manzani, P.R., \& Abe, A.S. 1988. Sobre dois novos métodos de preparo do hemipenis de serpentes. Memórias do Instituto Butantan. 50(1): 15-20.

Meneses-Pelayo, E., \& Passos, P. 2019. New polychromatic species of Atractus (Serpentes: Dipsadidae) from the eastern portion of the Colombian Andes. Copeia. 107(2): 250-261. doi.org/10.1643/CH-18-163.

Moraes-Da-Silva, A., Amaro, R.C., Nunes, P.M.S., Strüssmann, C., Teixeira, M.J., Andrade, A.J., Sudré, V., Recoder, R., Rodrigues, M.T., \& Curcio, F. F. 2019. Chance, luck and a fortunate finding: a new species of watersnake of the genus Helicops Wagler, 1828 (Serpentes:

Xenodontinae), from the Brazilian Pantanal wetlands. Zootaxa, 4651(3): 445-470. doi.org/10.11646/zootaxa.4651.3.3.

Murta-Fonseca, R.A., Franco, F.L., \& Fernandes, D.S. 2015. Taxonomic status and morphological variation of Hydrodynastes bicinctus (Hermann, 1804) (Serpentes: Dipsadidae). Zootaxa. 4007(1): 63-81. doi.org/10.11646/zootaxa.4007.1.4

Myers, C.W., \& Cadle, J.E. 2003. On the snake hemipenis, with notes on Psomophis and techniques of eversion: a response to Dowling. Herpetological Review. 34(4): 295-302. Nogueira, C.C., Argôlo, A.J.S., Arzaendia, V., Azevedo, J.A., Barbo, F.E., Bérnils, R.S., Bolochio, B.E., Borges-Martins, M., Brasil-Godinho, M., Braz, H., Buononato, M.A.,CisnerosHeredia, D.F., Colli, G.R., Costa, H.C., Franco, F.L., Giraudo, A., Gonzalez, R.C., Guedes, T., Hoogmoed, M.S., Marques, O.A.V., Montingelli, G.G., Passos, P., Prudente, A.L.C., Rivas, G.A., Sanchez, P.M., Serrano, F.C., Silva Jr. N.J., Strüssmann, C., Vieira-Alencar, J.P.S., Zaher, H., Sawaya, R.J., \& Martins, M. 2019. Atlas of Brazilian snakes: verified point-locality maps to mitigate the Wallacean shortfall in a megadiverse snake fauna. South American Journal of Herpetology. 14(SI 1): 1-274. doi.org/10.2994/SAJH-D-19-00120.1

Nunes, P.M., Fouquet, A., Curcio, F.F., Kok, P.J., \& Rodrigues, M.T. 2012. Cryptic species in Iphisa elegans Gray, 1851 (Squamata: Gymnophthalmidae) revealed by hemipenial morphology and molecular data. Zoological Journal of the Linnean Society. 166(2): 361-376. doi:10.1111/j.1096-3642.2012.00846.x. 
438 Oksanen, J., Kindt, R., Legendre, P., O’Hara, B., Stevens, M.H.H. 2007. Vegan: community 439 ecology package, Department of Statistics and Mathematics, Vienna University of Economics 440 and Business Administration. Vienna. Accessed at: 2016.11.20.

441 Padial, J.M., \& De La Riva, I. 2010. A response to recent proposals for integrative taxonomy.

442 Biological Journal of the Linnean Society. 101(3): 747-756. doi.org/10.1111/j.1095-

443 8312.2010.01528.x.

444 Padial, J.M., Miralles, A., De la Riva, I., \& Vences, M. 2010. The integrative future of

445 taxonomy. Frontiers in zoology. 7(1): 1-14. doi.org/10.1186/1742-9994-7-16.

446 Palumbi, S., Martin, A., Romano, S., McMillan, W.O., Stice, L., \& Grabowski, G. 2002. The

447 simple fool's guide to PCR, version 2.0. Honolulu, EUA.

448 Pante, E., Schoelinck, C., \& Puillandre, N. 2014. From integrative taxonomy to species

449 description: one step beyond. Systematic Biology. 64(1): 152-160.

450 Passos, P., and A. L. C. Prudente. 2012. Morphological variation, polymorphism, and taxonomy

451 of the Atractus torquatus complex (Serpentes: Dipsadidae). Zootaxa. 3407(1): 1-21.

452 Passos, P., Martins, A., \& Pinto-Coelho, D. 2016. Population morphological variation and

453 natural history of Atractus potschi (Serpentes: Dipsadidae) in Northeastern Brazil. South

454 American Journal of Herpetology. 11(3): 188-211. doi.org/10.2994/SAJH-D-16-00034.1.

455 Patton, J.L., Da Silva, M.N.F., \& Malcolm, J.R. 1994. Gene genealogy and differentiation among

456 arboreal spiny rats (Rodentia: Echimyidae) of the Amazon basin: a test of the riverine barrier

457 hypothesis. Evolution. 48(4): 1314-1323. doi:10.1111/j.1558-5646.1994.tb05315.x.

458 Pearse, D.E., \& Pogson, G.H. 2000. Parallel evolution of the melanic form of the California

459 legless lizard, Anniella pulchra, inferred from mitochondrial DNA sequence variation.

460 Evolution. 54(3): 1041-1046. doi.org/10.1111/j.0014-3820.2000.tb00104.X

461 Pellegrino, K., Rodrigues, M.T., Waite, A.N., Morando, M., Yassuda, Y.Y., \& Sites, J.W. 2005.

462 Phylogeography and species limits in the Gymnodactylus darwinii complex (Gekkonidae,

463 Squamata): genetic structure coincides with river systems in the Brazilian Atlantic Forest.

464 Biological Journal of the Linnean Society. 85(1): 13-26. doi.org/10.1111/j.1095-

465 8312.2005.00472.x.

466 Pereira-Filho, G.A., \& Montingelli, G.G. 2006. Geographic distribution Hydrodynastes gigas.

467 Herpetological Review. 37: 497.

468 Pesantes, O.S. 1994. A method for preparing the hemipenis of preserved snakes. Journal of

469 Herpetology. 28(1): 93-95. doi:10.2307/1564686.

470 Peters, J.A. 1964. Dictionary of Herpetology - a brief and meaningful definition of words and

471 terms used in herpetology. New York Hafner Publishing Company.

472 Peters, J.A., \& Orejas-Miranda, B. 1970. Catalogue of the Neotropical Squamata. Part I. Snakes.

473 Bulletin United States National museum 1-347.

474 Pook, C.E., Wüster, W., \& Thorpe, R.S. 2000. Historical biogeography of the western rattlesnake

475 (Serpentes: Viperidae: Crotalus viridis), inferred from mitochondrial DNA sequence

476 information. Molecular Phylogenetics and Evolution. 15(2): 269-282.

477 doi.org/10.1006/mpev.1999.0756. 
478 R Core Team. 2014. A language and environment for statistical computing. Vienna. Accessed at: 4792016.11 .20

480 Rambaut, A., Suchard, M.A., Xie, D. \& Drummond, A.J. 2014. Tracer v1.6. - Disponível em 481 http://beast.bio.ed.ac.uk/Tracer, acessado em 10 setembro de 2019.

482 Recoder, R.S., De Pinho Werneck, F., Teixeira Jr, M., Colli, G.R., Sites Jr, J.W., \& Rodrigues, 483 M.T. 2014. Geographic variation and systematic review of the lizard genus Vanzosaura 484 (Squamata, Gymnophthalmidae), with the description of a new species. Zoological Journal of the 485 Linnean Society. 171(1): 206-225. doi: 10.1111/zoj.12128.

486 Rocha, R.G., Ferreira, E., Loss, A.C., Heller, R., Fonseca, C., \& Costa, L.P. 2015. The Araguaia 487 river as an important biogeographical divide for didelphid marsupials in central Brazil. Journal of 488 Heredity. 106(5): 593-607. doi.org/10.1093/jhered/esv058.

489 Ronquist, F., \& Huelsenbeck, J.P. 2003. MrBayes 3: Bayesian phylogenetic inference under 490 mixed models. Bioinformatics. 19(12): 1572-1574. doi:10.1093/bioinformatics/btg180.

491 Ruane, S., Myers, E.A., Lo, K., Yuen, S., Welt, R.S., Juman, M., Futterman, I., Nussbaum, R.A., 492 Schneider, G., Burbrink, F.T \& Raxworthy, C.J. 2018. Unrecognized species diversity and new 493 insights into colour pattern polymorphism within the widespread Malagasy snake Mimophis 494 (Serpentes: Lamprophiidae). Systematics and Biodiversity. 16(3): 229-244. 495 doi.org/10.1080/14772000.2017.1375046.

496 Sabaj-Pérez, M.H. 2014. Standard symbolic codes for institutional resource collections in 497 herpetology and ichthyology: an Online Reference. Version 5.0. American Society of 498 Ichthyologists and Herpetologists, Washington, DC. Available from: http://www.asih.org 499 (accessed 24 November 2019).

500 Sambrook, J., Fritsch, E.F., \& Maniatis, R. 1989. Molecular cloning: a laboratory manual. Cold 501 Spring Harbor Laboratory Press, New York.

502 Santos Jr, A.P., Adams, G.B., Buhler, D., Ribeiro, S., \& Carvalho, T.S. 2017. Distribution 503 extension for Hydrodynastes melanogigas Franco, Fernandes \& Bentim, 2007 (Serpentes: 504 Dipsadidae: Xenodontinae) in the Araguaia-Tocantins basin, Brazilian Cerrado. Check List. 505 13(3): 2135-2136. doi:10.15560/13.3.2135.

506 Silva Jr, N.J., Hamdan, B., Tonial, I., Silva, H.L.R., and Cintra, C. (2012). Hydrodynastes 507 melanogigas Franco, Fernandes and Bentim, 2007 (Squamata: Serpentes: Colubridae): range 508 extension and new state record. Check List. 8(4): 813-814. doi:10.15560/8.4.813.

509 Tamura, K., Stecher, G., Peterson, D., Filipski, A. \& Kumar, S. 2013. MEGA6: molecular 510 evolutionary genetics analysis version 6.0. Molecular Biology and Evolution. 30(12): 2725511 2729. doi.org/10.1093/molbev/mst197.

512 Townsend, T.M., Alegre, R.E., Kelley, S.T., Wiens, J.J., \& Reeder, T.W. 2008. Rapid 513 development of multiple nuclear loci for phylogenetic analysis using genomic resources: an 514 example from squamate reptiles. Molecular Phylogenetics and Evolution. 47(1): 129-142. 515 doi:10.1016/j.ympev.2008.01.008.

516 Uetz, P., Cherikh, S., Shea, G., Ineich, I., Campbell, P.D., Doronin, I.V., Rosado, J., Wynn, A., 517 Tighe, K.A., Mcdiarmid, R., Lee, J.L., Köhler, G., Ellis, R., Doughty, P., Raxworthy, C.J., 
518 Scheinberg, L., Resetar, A., Sabaj, M., Schneider, G., Franzen, M., Glaw, F., Böhme, W., 519 Schweiger, S., Gemel, R., Couper, P., Amey, A., Dondorp, E., Ofer, G., Meiri, S., \& Wallach, V. 520 2019. A global catalog of primary reptile type specimens. Zootaxa. 4695(5): 438-450.

521 doi.org/10.11646/zootaxa.4695.5.2.

522 Vanzolini, P.E., Ramos-Costa, A.M.M., \& Vitt, L.J. 1980. Répteis das caatingas. Academia 523 Brasileira de Ciências.

524 Vidal, N., Dewynter, M., \& Gower, D.J. 2010. Dissecting the major American snake radiation: A 525 molecular phylogeny of the Dipsadidae Bonaparte (Serpentes, Caenophidia). Comptes Rendus 526 Biologies. 333(1): 48-55. doi:10.1016/j.crvi.2009.11.003.

527 Wallach, V., Williams, K.L., \& Boundy, J. 2014. Snakes of World: A catalogue of living and 528 extinct species. CRC Press, London New York.

529 Zaher, H. 1999. Hemipenial morphology of the South American xenodontine snakes, with a 530 proposal for a monophyletic Xenodontinae and a reappraisal of colubroid hemipenes. Bulletin of 531 the American Museum of Natural History. 240: 1-168.

532 Zaher, H., \& Prudente, A.L.C. 2003. Hemipenes of Siphlophis (Serpentes, Xenodontinae) and 533 techniques of hemipenial preparation in snakes: a response to Dowling. Herpetological Review. 534 34(4): 302-306.

535 Zaher, H., Murphy, R.W., Arredondo, J.C., Graboski, R., Machado-Filho, P.R., Mahlow, K., 536 Montingelli, G.G., Quadros, A. B., Orlov, N.L., Wilkinson, M., Zhang, Y.P., \& Grazziotin, F.G. 537 2019. Large-scale molecular phylogeny, morphology, divergence-time estimation, and the fossil 538 record of advanced caenophidian snakes (Squamata: Serpentes). PloS One, 14(5): 1-82.

539 doi.org/10.1371/journal.pone.0216148. 


\section{Figure 1}

Distribution of analyzed data in this study.

Sample localities for (a) molecular and (b) morphology of Hydrodynastes analyzed in this study.

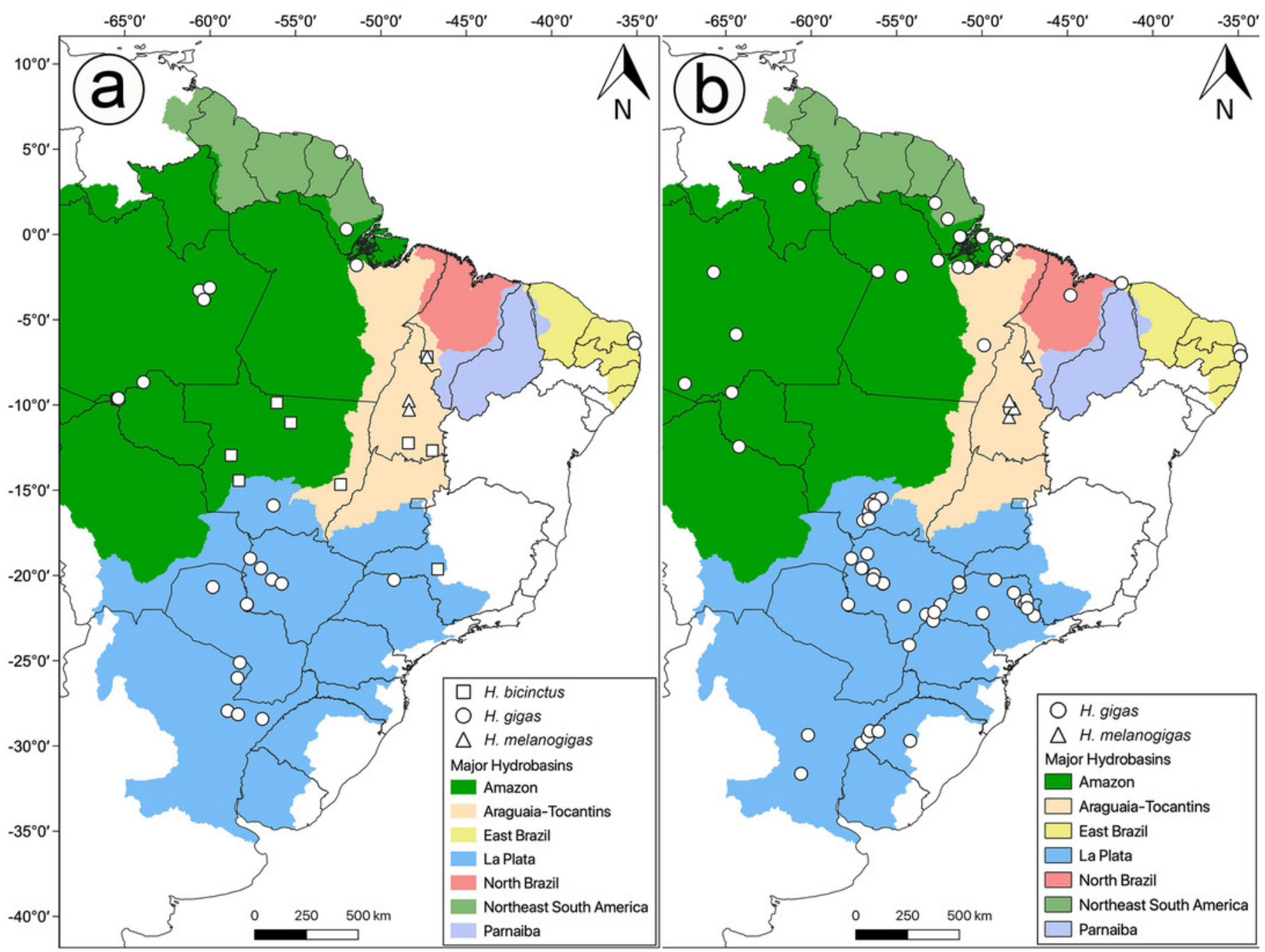


Figure 2

Concatenated tree (16S, Cytb, C-mos and NT3) of the genus Hydrodynastes recovered by Bayesian analysis in MrBayes.

Numbers near the nodes correspond to support values indicate by posterior probability (pp). Asterisks indicate samples identified as H. melanogigas. Photo credit: Karoline Ceron. 


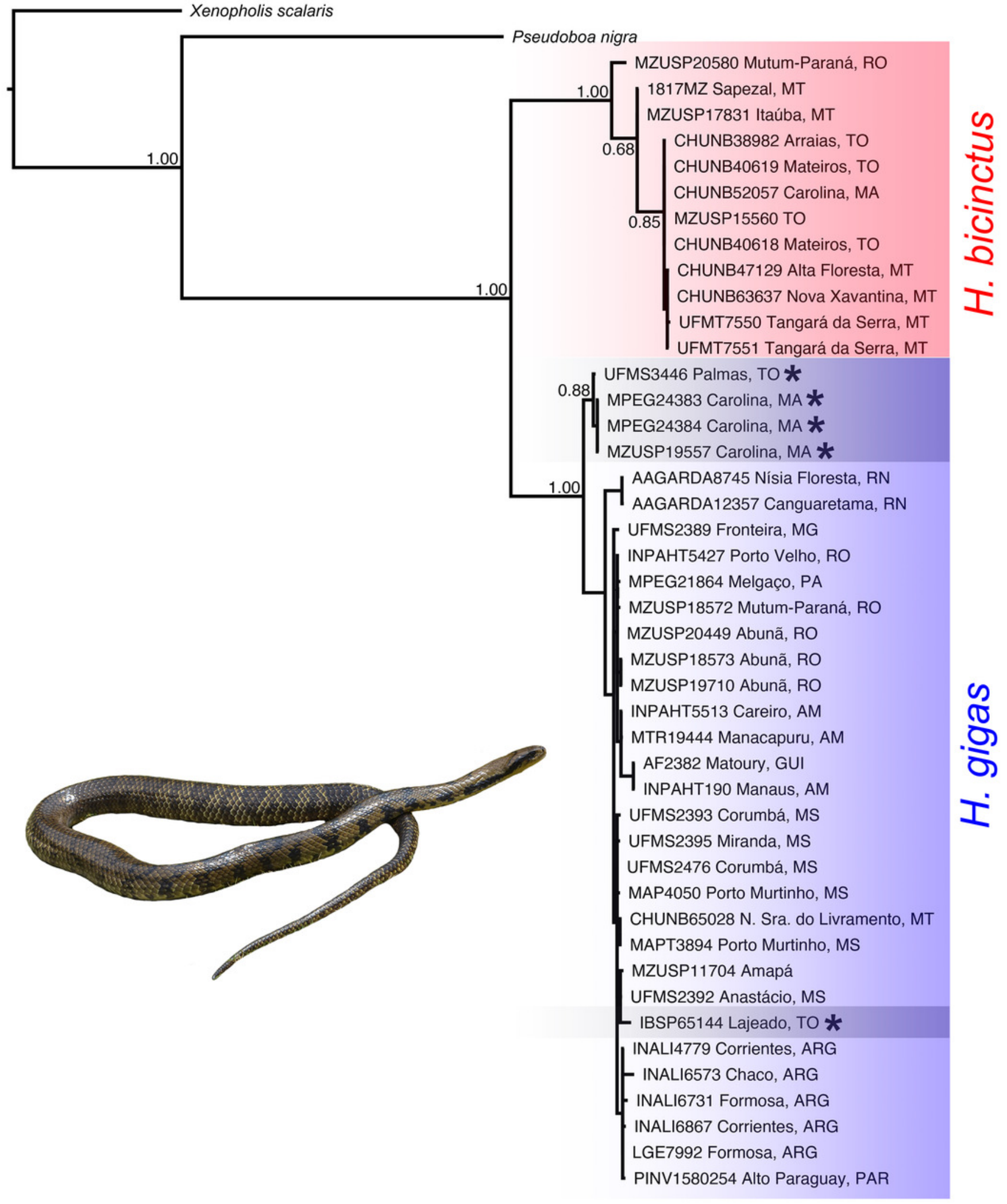


Figure 3

Results of a Principal Component Analysis (PCA) on the morphometric variables.

Males (a) and Females (b) of Hydrodynastes gigas and H. melanogigas. Black circle corresponds to $H$. gigas and red circle to $H$. melanogigas. SVL: snout-vent length; HL: head length; HW: head width; DN: distance between nostrils; EN: distance between eye and nostril; ED: eye diameter; $\mathrm{HH}$ : head height.

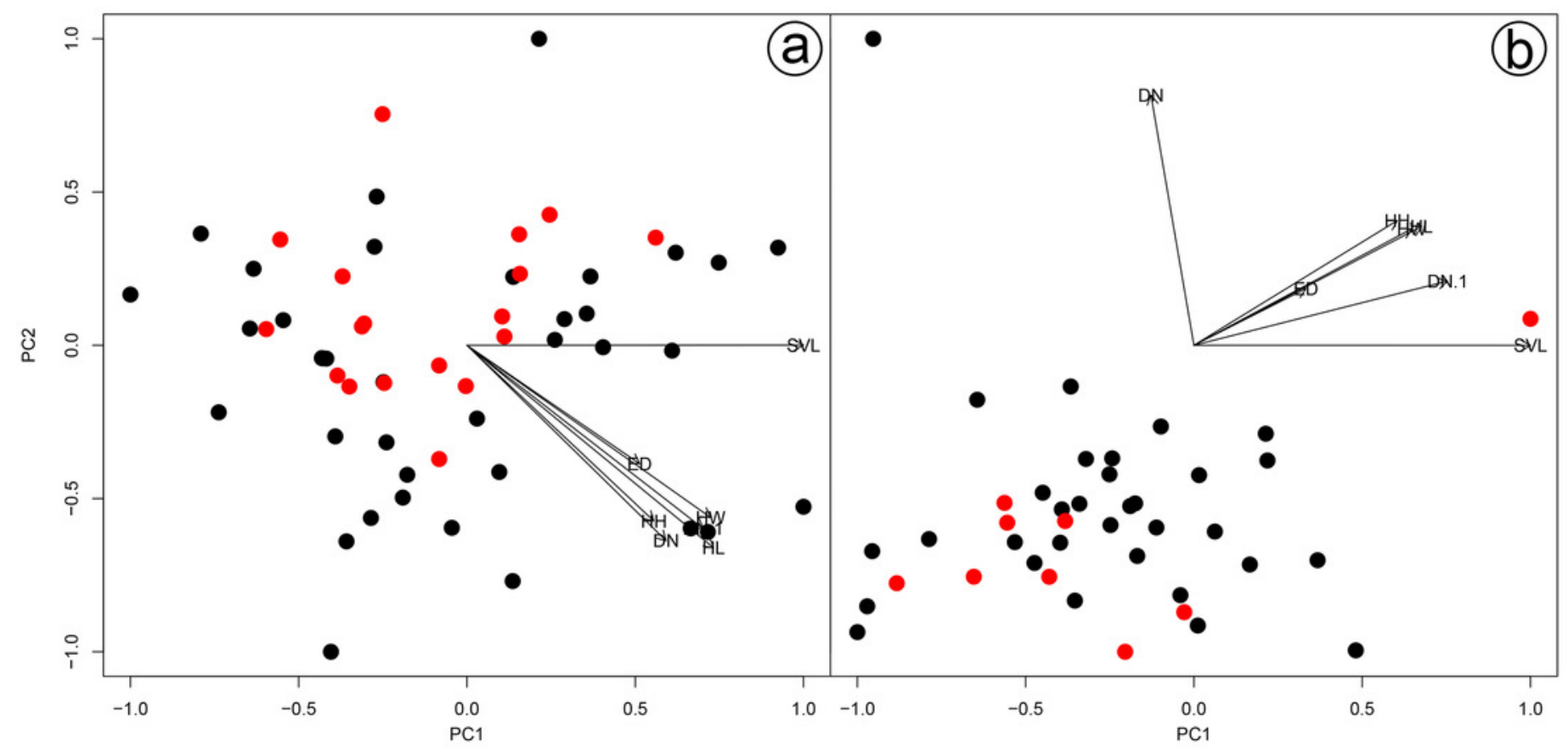




\section{Figure 4}

Dorsal and ventral view of the melanism gradient in Hydrodynastes melanogigas.

MZCEULP 1218 (a, b); MZCEULP 516 (c, d) ; MZCEULP 1046 (e, f); MZCEULP 1273 (g, h); MZCEULP 758 (i, j); MZCEULP 938 (k, I). All specimens from Tocantins-Araguaia basin. Scale of $50 \mathrm{~mm}$.

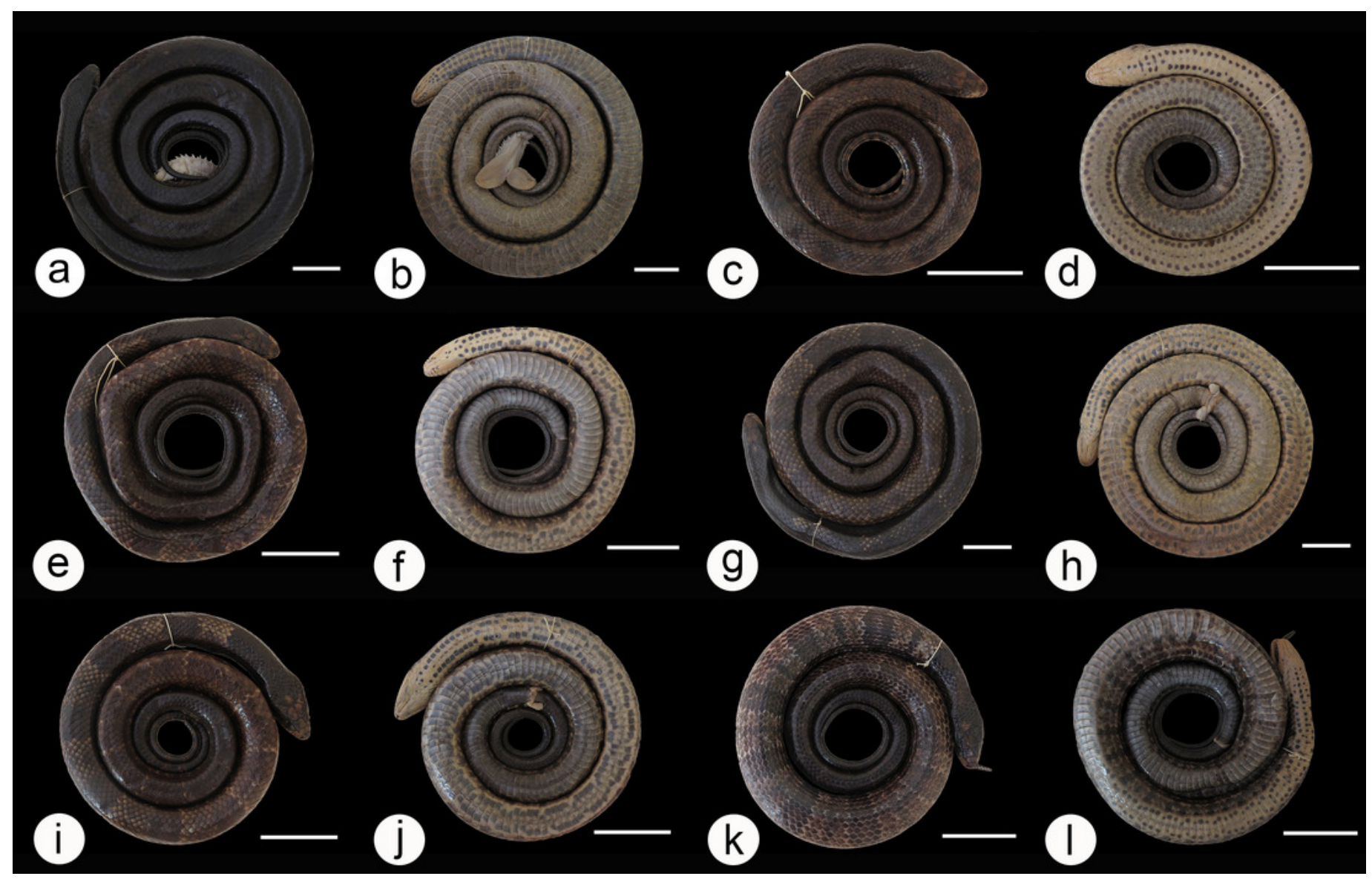




\section{Figure 5}

Dorsal and ventral view of the coloration gradient in Hydrodynastes gigas.

La Plata basin UFMT 9076 (a, b); Amazon basin CHUNB 15159 (c, d); Tocantins-Araguaia basin MPEG $18012(\mathrm{e}, \mathrm{f})$, MPEG $18071(\mathrm{~g}, \mathrm{~h})$, MPEG $18046(\mathrm{i}, \mathrm{j})$, MPEG $18070(\mathrm{k}, \mathrm{l})$. Scale of $50 \mathrm{~mm}$.

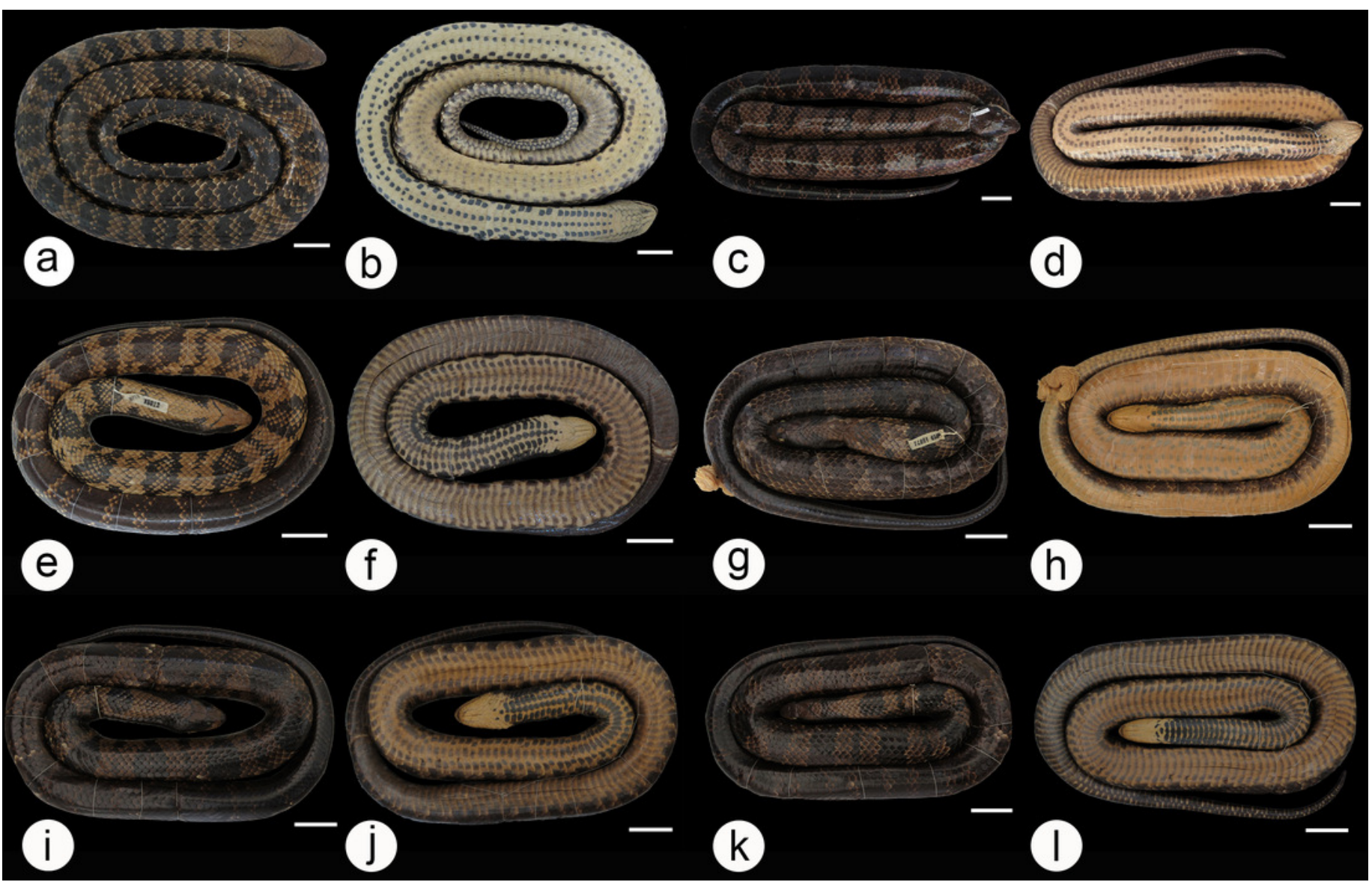


Figure 6

Dorsal and ventral view of the body and lateral view of the head in Hydrodynastes gigas.

Amazon basin MPEG 22652 (a, b, c), CHUNB 56729 (d, e, f), MPEG 18674 (g, h, i); East Brazil CHUFPB 4611 (j, k, l); La Plata Basin UFMT 026 (m, n, o), ZUFMS 2389 (p, q, r). Scale of $50 \mathrm{~mm}$ for body view and scale of $20 \mathrm{~mm}$ head view. 


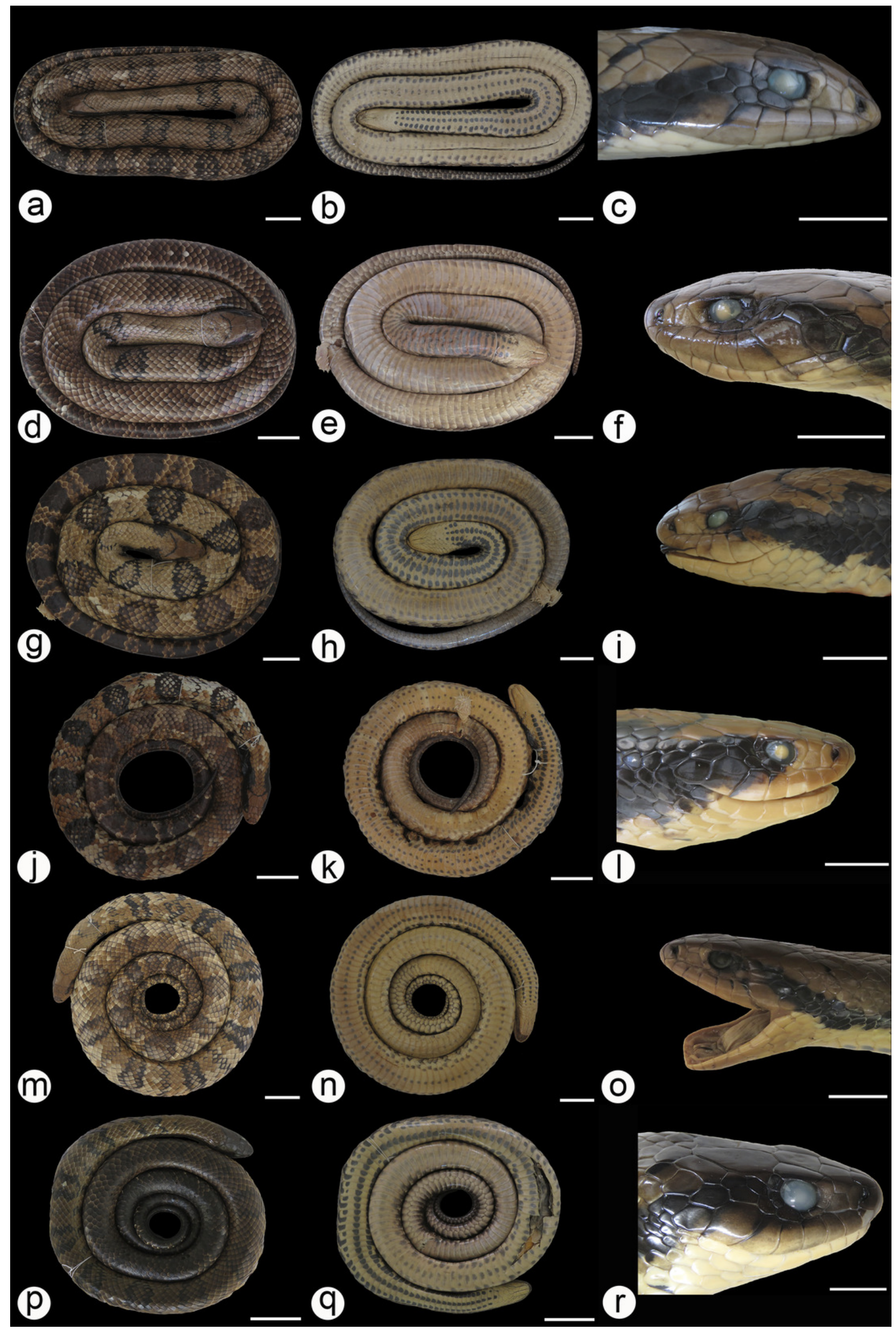

Peerj reviewing PDF | (2020:04:48410:2:0:NEW 5 Sep 2020) 


\section{Figure 7}

Dorsal and ventral view of the ontogenetic variation in Hydrodynastes gigas.

Amazon basin CHUNB 66534 (a, b); Parnaiba basin CZDP 077 (c, d); East Brazil CHUFPB 14837 (e, f); La Plata basin ZUFMS 1603 (g, h); Tocantins-Araguaia basin CHUNB 22053 (i, j). Scale of $30 \mathrm{~mm}$. 


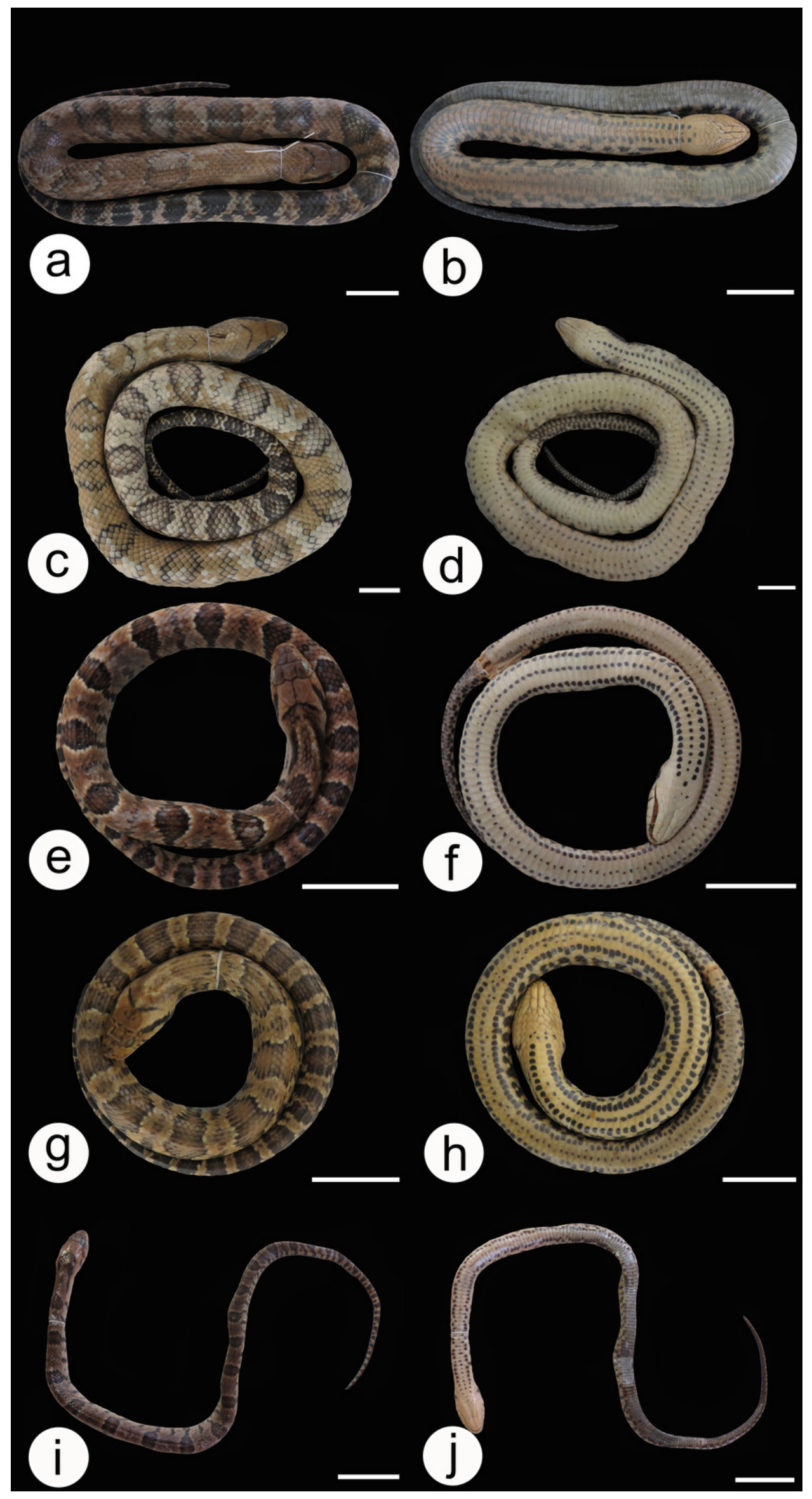

Peerj reviewing PDF | (2020:04:48410:2:0:NEW 5 Sep 2020) 


\section{Figure 8}

Hemipenial morphology.

Hydrodynastes gigas: Amazon basin MZUSP 18572 (a) asulcate and (b) sulcate side.

Northeast South America basin MPEG 25438 (c) asulcate and (d) sulcate side. La plata basin ZUFMS 1910 (e) asulcate and (f) sulcate side; MHNCl 4511 (g) asulcate and (h) sulcate side; UFSM 1937 (i) asulcate and (j) sulcate side. Hydrodynastes melanogigas Tocantins-Araguaia basin CHUNB $12802(\mathrm{k})$ asulcate and (I) sulcate side. Scale of $10 \mathrm{~mm}$.

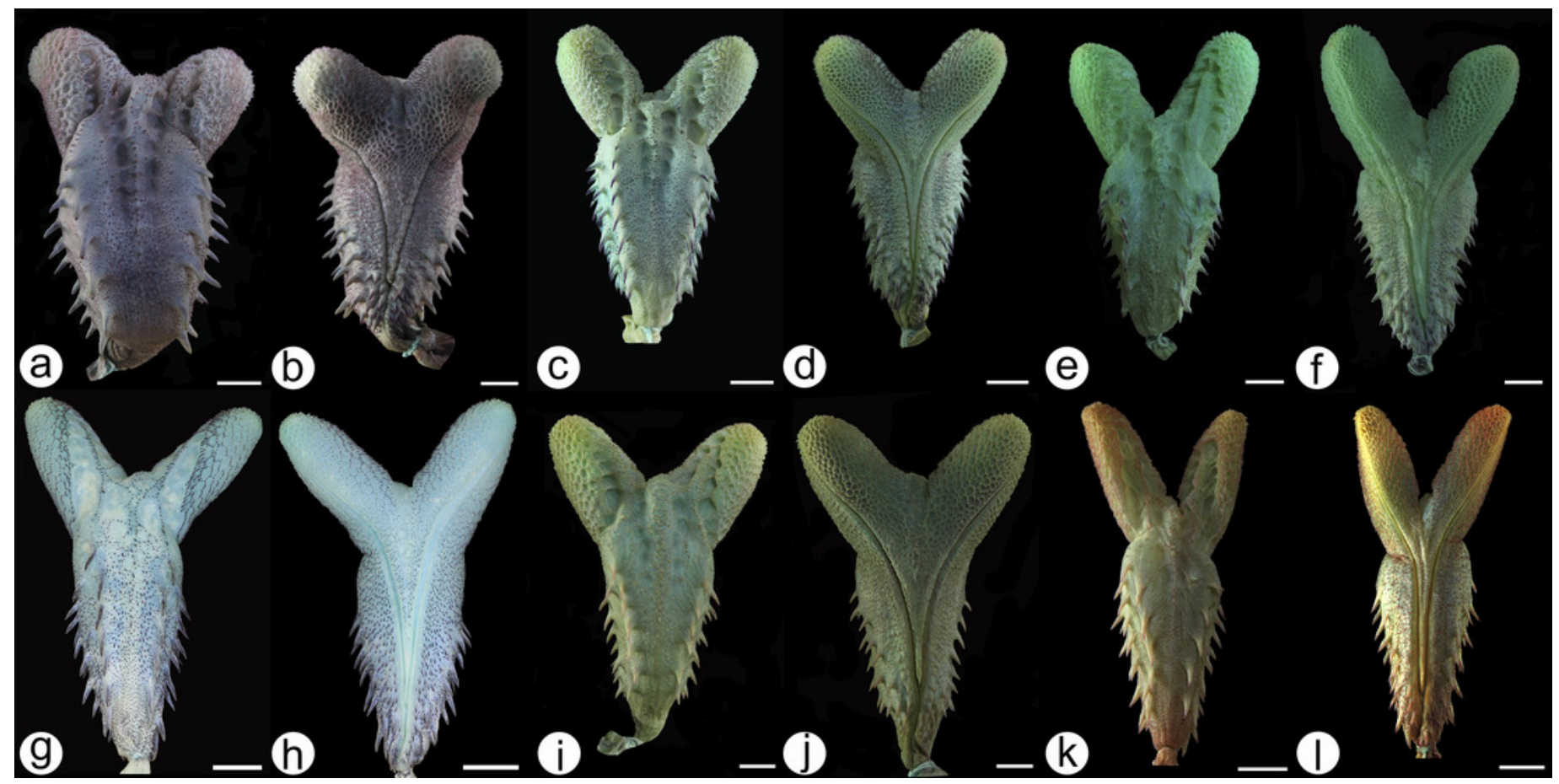




\section{Figure 9}

Dorsal and ventral views of the body and head.

Lectotype MNHN 3623 Hydrodynastes gigas. Credit: Hussam Zaher. Scale of 50mm for body view and scale of $10 \mathrm{~mm}$ head view.

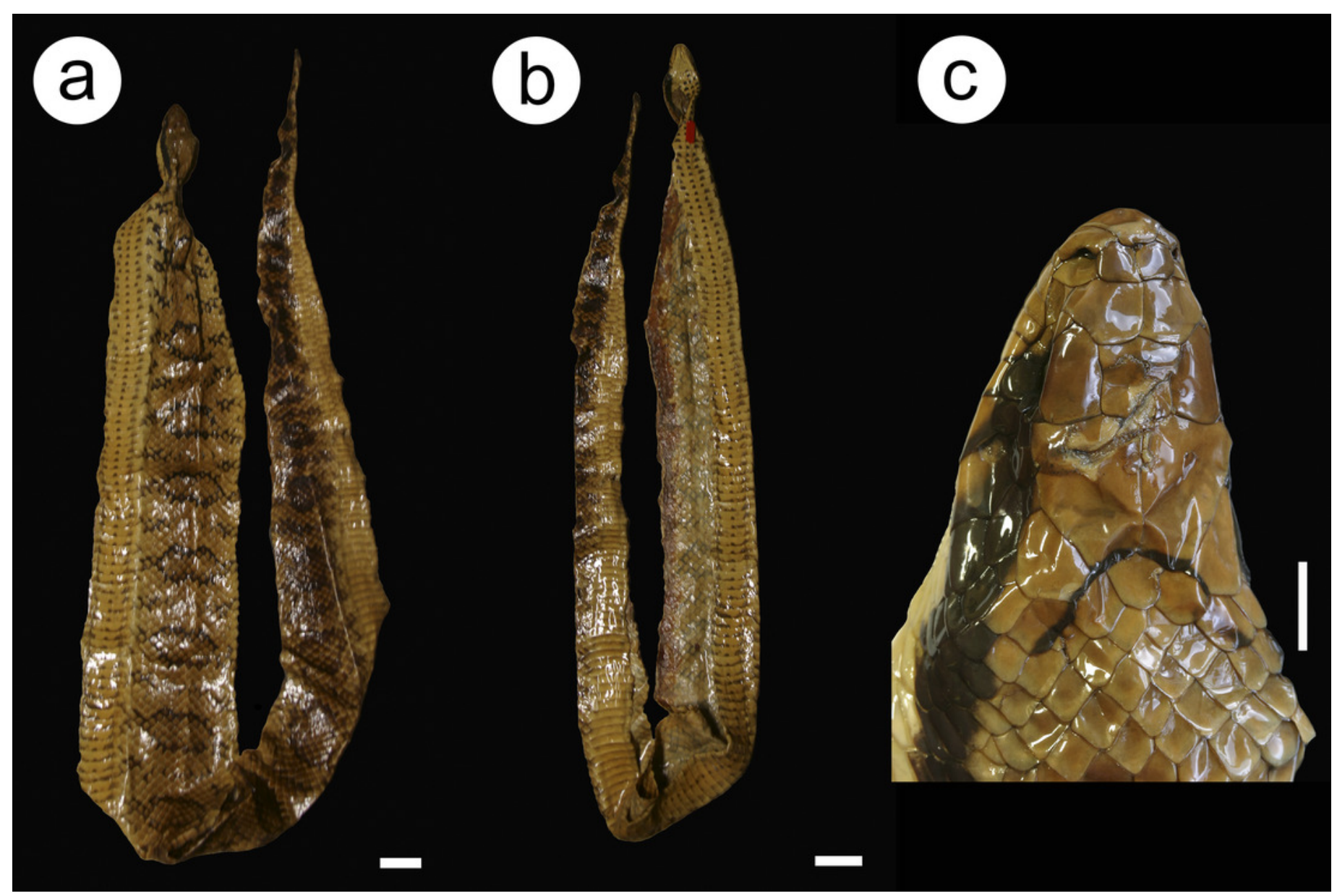


Figure 10

Geographic distribution of Hydrodynastes gigas in South America.

We compiled data from the literature, specimens and tissues analyzed. 


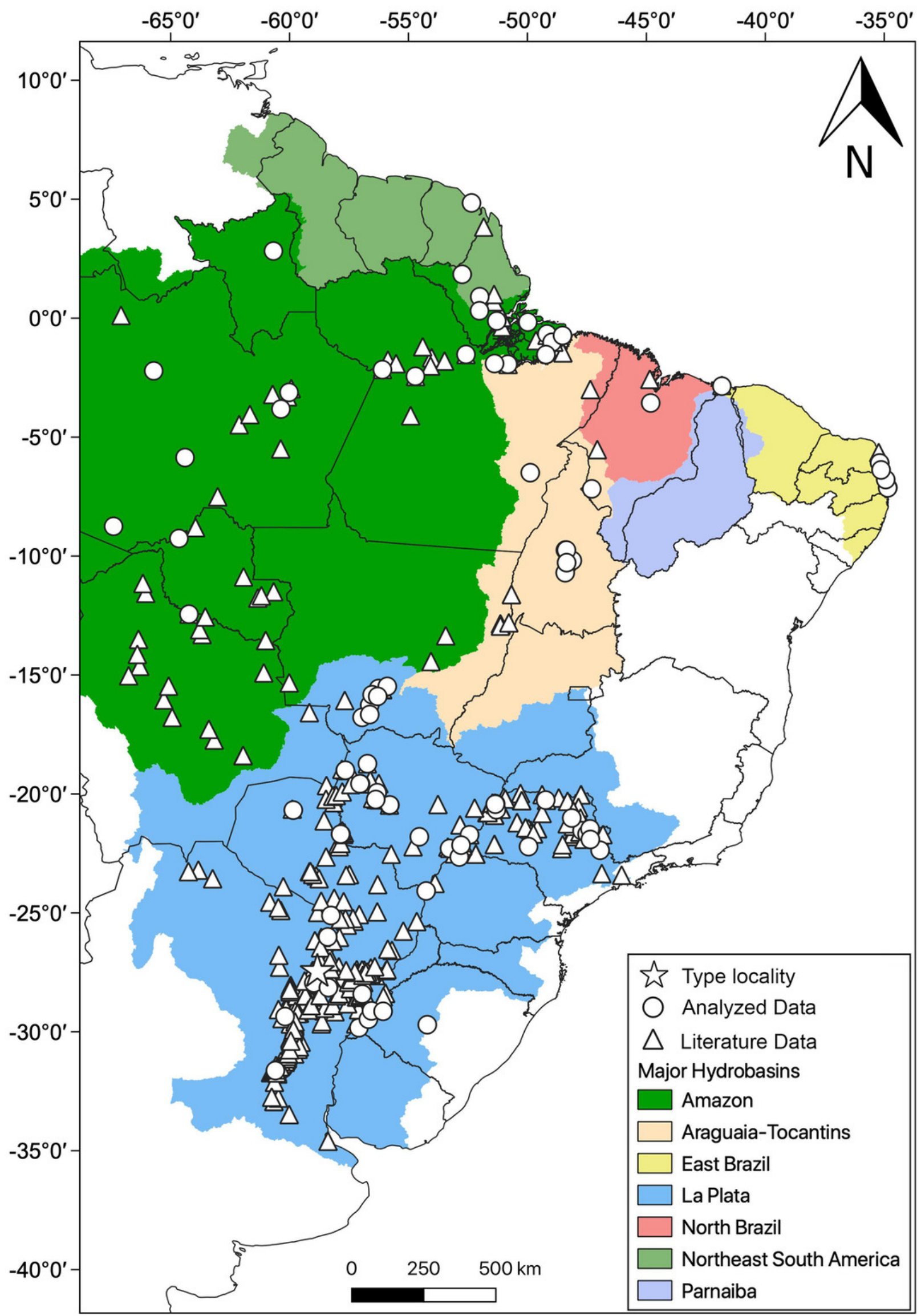




\section{Table 1 (on next page)}

Voucher information and GenBank numbers.

Specimens used for the molecular analyses, including GenBank numbers for mitochondrial $16 \mathrm{~S}$ and Cytb, nuclear Cmos and NT3 sequences. ${ }^{*}$ data not available in the original references. 


\begin{tabular}{|c|c|c|c|c|c|c|c|}
\hline \multirow{2}{*}{ Species } & \multirow{2}{*}{ Voucher } & \multirow{2}{*}{ Locality } & \multicolumn{4}{|c|}{ Genbank Accession number } & \multirow[t]{2}{*}{ Refer } \\
\hline & & & $16 S$ & Cytb & Cmos & NT3 & \\
\hline Hydrodynastes bicinctus & CHUNB52057 & Brazil, Maranhão, Carolina & MT192271 & MT224977 & МT328069 & МT328103 & This study \\
\hline Hydrodynastes bicinctus & CHUNB47129 & Brazil, Mato Grosso, Alta Floresta & MT192270 & MT224976 & - & - & This study \\
\hline Hydrodynastes bicinctus & CHUNB63637 & Brazil, Mato Grosso, Nova Xavantina & MT192272 & MT224978 & МТ328070 & MT328104 & This study \\
\hline Hydrodynastes bicinctus & MZUSP17831 & Brazil, Mato Grosso, Itaúba & MT192274 & MT224980 & МT328072 & MT328105 & This study \\
\hline Hydrodynastes bicinctus & UFMT7550 & Brazil, Mato Grosso, Tangará da Serra & MT192276 & MT224981 & МТ328073 & MT328107 & This study \\
\hline Hydrodynastes bicinctus & UFMT7551 & Brazil, Mato Grosso, Tangará da Serra & MT192277 & MT224982 & MT328074 & MT328108 & This study \\
\hline Hydrodynastes bicinctus & 1817 (MZUSP) & Brazil, Mato Grosso, Sapezal & MT192267 & MT224972 & MT328065 & MT328100 & This study \\
\hline Hydrodynastes bicinctus & MZUSP20580 & Brazil, Rondônia, Porto Velho, Mutum & MT192275 & - & - & MT328106 & This study \\
\hline Hydrodynastes bicinctus & CHUNB38982 & Brazil, Tocantins, Arraias & MT192268 & MT224973 & МT328066 & - & This study \\
\hline Hydrodynastes bicinctus & CHUNB40618 & Brazil, Tocantins, Mateiros & - & MT224974 & МT328067 & MT328101 & This study \\
\hline Hydrodynastes bicinctus & CHUNB40619 & Brazil, Tocantins, Mateiros & MT192269 & MT224975 & MT328068 & MT328102 & This study \\
\hline Hydrodynastes bicinctus & MZUSP15560 & Brazil, Tocantins, UHE Peixe Angical & MT192273 & MT224979 & МT328071 & - & This study \\
\hline Hydrodynastes gigas & INALI6573 & Argentina, Chaco, San Fernando & MT192283 & MT224989 & - & МT328114 & This study \\
\hline Hydrodynastes gigas & INALI4779 & Argentina, Corrientes, General San Martín & MT192282 & MT224988 & - & MT328113 & This study \\
\hline Hydrodynastes gigas & INALI6867 & Argentina, Corrientes, Mburucuya & MT192285 & MT224991 & - & MT328116 & This study \\
\hline Hydrodynastes gigas & LGE7992 & Argentina, Formosa, Pirané & MT192287 & MT224995 & - & MT328119 & This study \\
\hline Hydrodynastes gigas & INALI6731 & Argentina, Formosa, Pilcomayo & MT192284 & MT224990 & - & MT328115 & This study \\
\hline Hydrodynastes gigas & MZUSP11704 & Brazil, Amapá & MT192289 & MT225000 & - & MT328124 & This study \\
\hline Hydrodynastes gigas & INPA-HT5513 & Brazil, Amazonas, Careiro & MT215328 & MT224994 & МT328081 & MT328118 & This study \\
\hline Hydrodynastes gigas & INPA-HT190 & Brazil, Amazonas, Manaus & MT215327 & MT224992 & МТ328079 & MT328117 & This study \\
\hline Hydrodynastes gigas & MTR19444 & Brazil, Amazonas, Manacapuru & MT215333 & MT224999 & МT328086 & MT328123 & This study \\
\hline Hydrodynastes gigas & CHUNB65028 & Brazil, Mato Grosso, Nossa Senhora do Livramento & MT192281 & MT224986 & МT328077 & MT328111 & This study \\
\hline Hydrodynastes gigas & MAP-T3894 & Brazil, Mato Grosso do Sul, Porto Murtinho & MT215330 & MT224997 & MT328083 & MT328121 & This study \\
\hline Hydrodynastes gigas & MAP4050 & Brazil, Mato Grosso do Sul, Porto Murtinho & MT215329 & MT224996 & MT328082 & MT328120 & This study \\
\hline Hydrodynastes gigas & ZUFMS-REP2392 & Brazil, Mato Grosso do Sul, Anastácio & MT192296 & MT225007 & МT328092 & MT328130 & This study \\
\hline
\end{tabular}


Hydrodynastes gigas

Hydrodynastes gigas

Hydrodynastes gigas

Hydrodynastes gigas

Hydrodynastes gigas

Hydrodynastes gigas

Hydrodynastes gigas

Hydrodynastes gigas

Hydrodynastes gigas

Hydrodynastes gigas

Hydrodynastes gigas

Hydrodynastes gigas

Hydrodynastes gigas

Hydrodynastes gigas

Hydrodynastes melanogigas

Hydrodynastes melanogigas

Hydrodynastes melanogigas

Hydrodynastes melanogigas

Hydrodynastes melanogigas

Pseudoboa nigra

Xenopholis scalaris
ZUFMS-REP 2393

ZUFMS-REP 2395

ZUFMS-REP 2476

ZUFMS-REP 2389

AAGARDA8745

AAGARDA12357

INPA-HT5427

MZUSP18572

MZUSP18573

MZUSP19710

MZUSP20449

AF2382

PINV1580254

MPEG24383

MPEG24384

MZUSP19557

IBSP65144

UFMS-REP3446

MZUSP13278

KU222204
MPEG21864
Brazil, Mato Grosso do Sul, Corumbá Brazil, Mato Grosso do Sul, Miranda

Brazil, Mato Grosso do Sul, Corumbá

Brazil, Minas Gerais, Fronteira

Brazil, Pará, Melgaço

Brazil, Rio Grande do Norte, Nísia Floresta

Brazil, Rio Grande do Norte, Canguaretama

Brazil, Rondônia, Porto Velho, Teotônio

Brazil, Rondônia, Porto Velho, Mutum

Brazil, Rondônia, Porto Velho, Abunã

Brazil, Rondônia, Porto Velho, Abunã

Brazil, Rondônia, Porto Velho, Abunã

French Guiana, Matoury

Paraguay, Alto Paraguay

Brazil, Maranhão, Carolina

Brazil, Maranhão, Carolina

Brazil, Maranhão, Carolina

Brazil, Tocantins, Lajeado

Brazil, Tocantins, Palmas

*

\begin{tabular}{rrrrll} 
MT192297 & MT225008 & MT328093 & MT328131 & This study \\
MT192298 & MT225009 & MT328094 & MT328132 & This study \\
MT192299 & MT225010 & MT328095 & MT328133 & This study \\
MT192295 & MT225006 & MT328091 & MT328129 & This study \\
MT192288 & MT224998 & MT328084 & MT328122 & This study \\
MT192278 & MT224983 & MT328075 & MT328109 & This study \\
MT192279 & MT224984 & - & - & This study \\
MT192286 & MT224993 & MT328080 & - & This study \\
MT192290 & MT225001 & MT328087 & MT328125 & This study \\
MT192291 & MT225002 & MT328088 & MT328126 & This study \\
MT192292 & MT225003 & MT328089 & MT328127 & This study \\
MT192293 & MT225004 & MT328090 & MT328128 & This study \\
MT192280 & MT224985 & MT328076 & MT328110 & This study \\
MT192294 & MT225005 & - & MT424769 & This study \\
MT215331 & MT225012 & - & MT328097 & This study \\
MT215332 & MT225013 & MT328085 & MT328098 & This study \\
MT215334 & MT225014 & - & MT328099 & This study \\
- & MT224987 & MT328078 & MT328112 & This study \\
MT215335 & MT225011 & MT328096 & MT328134 & This study \\
GQ457764 & JQ598948 & GQ457885 & - & Zaher et al. 2009 \\
JQ598915 & GQ895897 & JQ599002 & - & Pyron et al. 2009 \\
& & & & Grazziotin et al. \\
\hline & & & & \\
\hline
\end{tabular}




\section{Table 2 (on next page)}

PartitionFinder 2 model of nucleotide substitution.

Best-fitting partitioning scheme model of nucleotide substitution for 16S, Cytb, Cmos and NT3 genes. 


\begin{tabular}{ll}
\hline Partitioning scheme & Model \\
\hline Cytb1, 16S & GTR $+\mathrm{G}$ \\
Cytb2, Cmos2 & HKY +I \\
Cytb3 & HKY $+\mathrm{G}$ \\
NT32, Cmos3, Cmos1 & JC \\
NT31, NT33 & K80+I+G \\
\hline
\end{tabular}

1

Peer] reviewing PDF | (2020:04:48410:2:0:NEW 5 Sep 2020) 


\section{Table 3 (on next page)}

Meristic characters in Hydrodynastes gigas and Hydrodynastes melanogigas.

In parenthesis the sampled number (n). SLr = right supralabials; SLI = left supralabials; $I L r=$ right infralabials; III = left infralabials; $\mathrm{LO}=$ loreal; $\mathrm{PE}=$ preoculars; $\mathrm{PO}=$ postoculars; $\mathrm{SO}=$ suboculars; $\mathrm{AT}=$ anterior temporals; $\mathrm{PT}=$ posterior temporals; $\mathrm{NA}=$ nasal; $\mathrm{IL}+\mathrm{GI}=$ infralabials in contact with first pair of genials; $I L+G 2=$ infralabials in contact with second pair of genials; $A P=$ apical pits; $A D=$ anterior dorsal scale rows; $M D=$ midbody dorsal scale rows; $\mathrm{PD}=$ posterior dorsal scale rows; $\mathrm{PV}=$ preventrals; $\mathrm{VE}=$ ventral; $\mathrm{SC}=$ subcaudal. ${ }^{*} 75$ specimens present autotomized tail. ${ }^{* *}$ specimens present only the head or other body part. 


\begin{tabular}{|c|c|c|c|c|c|}
\hline \multirow[t]{2}{*}{ Variables } & \multicolumn{3}{|c|}{ Hydrodynastes gigas } & \multicolumn{2}{|c|}{ Hydrodynastes melanogigas } \\
\hline & Male & Female & Undetermined $^{* *}$ & Male & Female \\
\hline SLr & $\begin{array}{c}7(\mathrm{n}=1) ; 8(\mathrm{n}=62) ; 9 \\
(\mathrm{n}=2)\end{array}$ & $7(\mathrm{n}=1) ; 8(\mathrm{n}=68)$ & $8(n=6)$ & $8(n=22)$ & $7(\mathrm{n}=1) ; 8(\mathrm{n}=15) ; 8(\mathrm{n}=1)$ \\
\hline SLl & $8(n=64) ; 9(n=1)$ & $8(n=61) ; 9(n=5)$ & $8(n=6)$ & $8(n=22)$ & $8(\mathrm{n}=17)$ \\
\hline $\mathrm{ILr}$ & $\begin{array}{c}9(\mathrm{n}=5) ; 10(\mathrm{n}=37) ; 11 \\
(\mathrm{n}=21) ; 12(\mathrm{n}=1)\end{array}$ & $\begin{array}{l}9(\mathrm{n}=2) ; 10(\mathrm{n}=29) ; 11 \\
\quad(\mathrm{n}=31) ; 12(\mathrm{n}=5)\end{array}$ & $10(\mathrm{n}=3) ; 11(\mathrm{n}=2)$ & $\begin{array}{c}8(\mathrm{n}=1) ; 9(\mathrm{n}=2) ; 10(\mathrm{n}=17) \\
11(\mathrm{n}=2)\end{array}$ & $\begin{array}{c}9(\mathrm{n}=1) ; 10(\mathrm{n}=14) ; 11 \\
(\mathrm{n}=2)\end{array}$ \\
\hline Ill & $\begin{array}{c}9(\mathrm{n}=4) ; 10(\mathrm{n}=32) ; 11 \\
(\mathrm{n}=26)\end{array}$ & $\begin{array}{c}9(\mathrm{n}=3) ; 10(\mathrm{n}=24) ; 11 \\
(\mathrm{n}=35) ; 12(\mathrm{n}=4)\end{array}$ & $10(n=3) ; 11(n=3)$ & $\begin{array}{c}9(\mathrm{n}=4) ; 10(\mathrm{n}=16) ; 11 \\
(\mathrm{n}=2)\end{array}$ & $\begin{array}{c}10(\mathrm{n}=10) ; 11(\mathrm{n}=6) ; 12 \\
(\mathrm{n}=1)\end{array}$ \\
\hline LO & $1(n=68)$ & $1(n=69)$ & $1(n=7)$ & $1(n=22)$ & $1(n=17)$ \\
\hline $\mathrm{PE}$ & $1(\mathrm{n}=66) ; 2(\mathrm{n}=1)$ & $1(\mathrm{n}=68) ; 2(\mathrm{n}=1)$ & $1(n=7)$ & $1(\mathrm{n}=20) ; 2(\mathrm{n}=2)$ & $1(\mathrm{n}=16) ; 2(\mathrm{n}=1)$ \\
\hline PO & $2(\mathrm{n}=48) ; 3(19)$ & $\begin{array}{c}1(\mathrm{n}=1) ; 2(\mathrm{n}=64) ; 3 \\
(\mathrm{n}=4)\end{array}$ & $2(n=7)$ & $2(n=19) ; 3(n=3)$ & $2(n=17)$ \\
\hline $\mathrm{SO}$ & $2(\mathrm{n}=3) ; 3(\mathrm{n}=64)$ & $2(\mathrm{n}=4) ; 3(\mathrm{n}=65)$ & $3(n=7)$ & $3(n=22)$ & $3(n=17)$ \\
\hline AT & $1(\mathrm{n}=5) ; 2(60) ; 3(\mathrm{n}=2)$ & $\begin{array}{c}1(\mathrm{n}=5) ; 2(\mathrm{n}=62) ; 3 \\
(\mathrm{n}=2)\end{array}$ & $2(\mathrm{n}=5) ; 3(\mathrm{n}=1)$ & $2(\mathrm{n}=16) ; 3(\mathrm{n}=5) ; 4(\mathrm{n}=1)$ & $2(n=17)$ \\
\hline PT & $\begin{array}{c}1+2(n=5) ; 1+3(n=6) \\
2+1(n=1) ; 2+2(n=3) \\
2+3(n=49) ; 2+4(n=2) \\
3+3(n=2)\end{array}$ & $\begin{array}{c}2(n=1) ; 3(n=1) ; 1+2 \\
(n=3) ; 1+3(n=9) ; 2+2 \\
(n=7) ; 2+3(n=45) ; 2+4 \\
(n=1) ; 3+2(n=1) ; 3+3 \\
(n=1)\end{array}$ & $\begin{array}{c}2+2(\mathrm{n}=2) ; 2+3(\mathrm{n}=4) ; 2+4 \\
(\mathrm{n}=1)\end{array}$ & $\begin{array}{c}1+3(\mathrm{n}=3) ; 2+1(\mathrm{n}=1) ; 2+2 \\
(\mathrm{n}=2) ; 2+3(\mathrm{n}=15)\end{array}$ & $\begin{array}{c}1+3(\mathrm{n}=3) ; 2+2(\mathrm{n}=2) ; 2+3 \\
(\mathrm{n}=12)\end{array}$ \\
\hline NA & $2(n=68)$ & $2(n=69)$ & $2(n=7)$ & $2(n=22)$ & $2(n=17)$ \\
\hline $\mathrm{IL}+\mathrm{G} 1$ & $\begin{array}{c}\text { i-iv }(n=15) ; i-v(n=48) ; i- \\
\text { vi }(n=3)\end{array}$ & $\begin{array}{l}\text { i-ii }(n=1) ; i-i v(n=10) ; i-v \\
\quad(n=54) ; i-v i(n=3)\end{array}$ & $\mathrm{i}-\mathrm{iv}(\mathrm{n}=2) ; \mathrm{i}-\mathrm{v}(\mathrm{n}=5)$ & $\begin{array}{c}\text { i-iv }(n=1) ; i-v(n=19) ; i-v i \\
(n=2)\end{array}$ & $\mathrm{i}-\mathrm{v}(\mathrm{n}=16) ; \mathrm{i}-\mathrm{iv}(\mathrm{n}=1)$ \\
\hline $\mathrm{IL}+\mathrm{G} 2$ & $0(\mathrm{n}=2) ; \mathrm{v}-\mathrm{vi}(\mathrm{n}=7) ; \mathrm{v}$ & $0(\mathrm{n}=3) ; \mathrm{v}-\mathrm{vi}(\mathrm{n}=5) ; \mathrm{v}$ & $v(n=2) ;$ vi $(n=5)$ & v $(n=1) ;$ vi $(n=19) ;$ vii $(n=2)$ & vi $(n=15) ; v-v i(n=1)$; vi- \\
\hline
\end{tabular}




\begin{tabular}{|c|c|c|c|c|c|}
\hline \multirow[t]{2}{*}{ Variables } & \multicolumn{3}{|c|}{ Hydrodynastes gigas } & \multicolumn{2}{|c|}{ Hydrodynastes melanogigas } \\
\hline & $\begin{array}{c}\text { Male } \\
(\mathrm{n}=8) ; \text { vi }(\mathrm{n}=46) ; \text { vii } \\
(\mathrm{n}=3)\end{array}$ & $\begin{array}{c}\text { Female } \\
(\mathrm{n}=4) ; \text { vi }(\mathrm{n}=56) ; \text { vii } \\
(\mathrm{n}=1)\end{array}$ & Undetermined $^{* *}$ & Male & $\begin{array}{l}\text { Female } \\
\text { vii }(n=1)\end{array}$ \\
\hline AP & $2(\mathrm{n}=67)$ & $2(\mathrm{n}=69)$ & $2(n=4)$ & $2(n=22)$ & $2(n=17)$ \\
\hline $\mathrm{AD}$ & $\begin{array}{c}17(\mathrm{n}=1) ; 18(\mathrm{n}=1) ; 19 \\
(\mathrm{n}=59) ; 20(\mathrm{n}=3) ; 21 \\
(\mathrm{n}=4)\end{array}$ & $\begin{array}{c}18(\mathrm{n}=3) ; 19(\mathrm{n}=54) ; 20 \\
(\mathrm{n}=5) ; 21(\mathrm{n}=6)\end{array}$ & $19(\mathrm{n}=4)$ & $19(n=22)$ & $19(n=17)$ \\
\hline MD & $\begin{array}{c}17(\mathrm{n}=2) ; 18(\mathrm{n}=1) ; 19 \\
(\mathrm{n}=64)\end{array}$ & $17(\mathrm{n}=4) ; 19(\mathrm{n}=65)$ & $17(\mathrm{n}=1) ; 19(\mathrm{n}=3)$ & $17(\mathrm{n}=3) ; 19(\mathrm{n}=19)$ & $18(\mathrm{n}=1) ; 19(\mathrm{n}=16)$ \\
\hline PD & $14(\mathrm{n}=1) ; 15(\mathrm{n}=67)$ & $\begin{array}{c}14(\mathrm{n}=1) ; 15(\mathrm{n}=67) ; 17 \\
(\mathrm{n}=1)\end{array}$ & $15(n=4)$ & $\begin{array}{c}14(\mathrm{n}=3) ; 15(\mathrm{n}=18) ; 16 \\
(\mathrm{n}=1)\end{array}$ & $15(\mathrm{n}=17)$ \\
\hline PV & $\begin{array}{c}1(\mathrm{n}=22) ; 2(\mathrm{n}=42) ; 3 \\
(\mathrm{n}=4)\end{array}$ & $\begin{array}{c}1(\mathrm{n}=18) ; 2(\mathrm{n}=45) ; 3 \\
(\mathrm{n}=6)\end{array}$ & $1(\mathrm{n}=2) ; 2(\mathrm{n}=1)$ & $1(\mathrm{n}=10) ; 2(\mathrm{n}=12)$ & $1(\mathrm{n}=4) ; 2(\mathrm{n}=13)$ \\
\hline VE & $150-164$ & $152-169$ & & $154-168$ & $168-172$ \\
\hline $\mathrm{SC}^{*}$ & $58(9)-88$ & $49(30)-84$ & & $71-86$ & $70(24)-79$ \\
\hline
\end{tabular}




\section{Table 4 (on next page)}

Morphometric measurement in Hydrodynastes gigas and Hydrodynastes melanogigas.

In parenthesis the sampled number (n). SVL = snout-vent length (from the tip of the snout to the cloaca); $T L=$ tail length; $H L$ = head length (from the tip of the snout to the quadratemandibular articulation); HW = head width (length of the widest part of head); DN = distance between nostrils (maximum distance between the nostrils); EN = distance between eye and nostril; $\mathrm{ED}=$ eye diameter; $\mathrm{HH}=$ head height (maximum distance between the base of the mandible and the parietal surface. 


\begin{tabular}{|c|c|c|c|c|}
\hline \multirow[t]{2}{*}{ Variables } & \multicolumn{2}{|c|}{ Hydrodynastes gigas } & \multicolumn{2}{|c|}{ Hydrodynastes melanogigas } \\
\hline & Male & Female & Male & Female \\
\hline \multirow{2}{*}{ SVL } & $249-1747(n=68)$ & $277-1879(n=69)$ & $468-1548(n=22)$ & $524-2198(n=17)$ \\
\hline & $998 \pm 1059,25$ & $988.5 \pm 512.2$ & $1100.4 \pm 396.1$ & $1048.3 \pm 381.4$ \\
\hline \multirow{2}{*}{$\mathrm{TL}$} & $84(25)-580(n=68)$ & $71-543(n=69)$ & $180-548(n=22)$ & $105-532(n=17)$ \\
\hline & $302,5 \pm 392,44$ & $276.6 \pm 143.6$ & $351.5 \pm 141.5$ & $355.5 \pm 143.6$ \\
\hline \multirow{2}{*}{$\mathrm{HL}$} & $20.57-67.94(n=63)$ & $21.65-78.61(n=66)$ & $30.04-55.48(n=22)$ & $32.63-69.21(n=17)$ \\
\hline & $44,24 \pm 33,49$ & $44.5 \pm 15.6$ & $47.4 \pm 7.3$ & $46.7 \pm 10.3$ \\
\hline \multirow{2}{*}{ HW } & $7.24-21.54(n=67)$ & $7.19-21.77(n=69)$ & $9.12-17.89(n=22)$ & $9.80-47.25(n=17)$ \\
\hline & $10,0 \pm 0,17$ & $13.9 \pm 4.4$ & $14.9 \pm 2.6$ & $15.5 \pm 8.5$ \\
\hline \multirow{2}{*}{$\mathrm{DN}$} & $2.89-12.93(n=68)$ & $3.51-11.97(n=69)$ & $4.17-9.47(n=22)$ & $4.78-10.68(n=17)$ \\
\hline & $10,24 \pm 0,71$ & $7.6 \pm 4.9$ & $7.5 \pm 1.4$ & $7.0 \pm 1.6$ \\
\hline \multirow{2}{*}{ EN } & $3.19-12.55(n=68)$ & $3.70-14.01(n=69)$ & $5.09-9.44(n=22)$ & $4.88-11.58(n=17)$ \\
\hline & $9,98 \pm 0,18$ & $7.3 \pm 2.5$ & $7.8 \pm 1.2$ & $7.3 \pm 1.8$ \\
\hline \multirow{2}{*}{$\mathrm{ED}$} & $4.19-8.55(n=68)$ & $4.12-8.41(n=69)$ & $4.85-7.64(n=22)$ & $5.08-7.95(n=17)$ \\
\hline & $6,37 \pm 3,08$ & $6.1 \pm 1.3$ & $6.4 \pm 0.8$ & $6.2 \pm 0.8$ \\
\hline \multirow{2}{*}{$\mathrm{AC}$} & $7.17-25.63(n=61)$ & $8.03-26.76(n=62)$ & $11.39-21.26(n=22)$ & $9.98-27.64(n=17)$ \\
\hline & $10,21 \pm 0,33$ & $16.3 \pm 6.0$ & $16.8 \pm 2.8$ & $15.9 \pm 4.4$ \\
\hline
\end{tabular}




\section{Table 5 (on next page)}

Unconrrected p-distance of 16S (Lower left) and Cytb (Upper right) mitochondrial fragment gene for the genus Hydrodynastes.

Bold the $p$-distance between $H$. gigas and $H$. melanogigas for the two genes. 


\begin{tabular}{llccccc}
\hline & & 1 & 2 & 3 & 4 & 5 \\
\hline 1 & Xenopholis scalaris & & 0.367 & 0.347 & 0.376 & 0.366 \\
2 & Pseudoboa nigra & 0.084 & & 0.366 & 0.313 & 0.341 \\
3 & Hydrodynastes bicinctus & 0.126 & 0.118 & & 0.129 & 0.123 \\
4 & Hydrodynastes gigas & 0.128 & 0.097 & 0.043 & & $\mathbf{0 . 0 2 0}$ \\
5 & Hydrodynastes melanogigas & 0.130 & 0.099 & 0.042 & $\mathbf{0 . 0 1 1}$ & \\
\hline
\end{tabular}

